\title{
Mineralogical and chemical characteristics of newer dolerite dyke around Keonjhar, Orissa: Implication for hydrothermal activity in subduction zone setting
}

\author{
Piyali Sengupta*, Arijit Ray and Sayantani Pramanik \\ Department of Geology, Presidency University, 86/1 College Street, Kolkata 700 073, India. \\ ${ }^{*}$ Corresponding author.e-mail: piysen@yahoo.co.in
}

The newer dolerite dykes around Keonjhar within the Singbhum Granite occur in NE-SW, NW-SE and NNE-SSW trends. The mafic dykes of the present study exhibit several mineralogical changes like clouding of plagioclase feldspars, bastitisation of orthopyroxene, and development of fibrous amphibole (tremolite-actinolite) from clinopyroxene, which are all considered products of hydrothermal alterations. This alteration involves addition and subtraction of certain elements. Graphical analyses with alteration index and elemental abundances show that elements like Rb, Ba, Th, La and $\mathrm{K}$ have been added during the alteration process, whereas elements like $\mathrm{Sc}, \mathrm{Cr}, \mathrm{Co}, \mathrm{Ni}, \mathrm{Si}, \mathrm{Al}, \mathrm{Fe}, \mathrm{Mg}$ and $\mathrm{Ca}$ have been removed. It is observed that in spite of such chemical alteration, correlation between major and trace elements, characteristic of petrogenetic process, is still preserved. This might reflect systematic alteration (addition or subtraction) of elements without disturbing the original element to element correlation. It has also been established by earlier workers that the evolution of newer dolerite had occurred in an arc-back arc setting which may also be true for newer dolerites of the present study. This is evident from plots of pyroxene composition and whole rock composition of newer dolerite samples in different tectonic discrimination diagrams using immobile elements. The newer dolerite dykes of the Keonjhar area may thus be considered to represent an example of hydrothermal activity on mafic rocks in an arc setting.

\section{Introduction}

Proterozoic mafic dyke swarms are fairly common in the shield areas all over the world. In India, Proterozoic mafic dykes are widespread in the cratonic areas of Bundelkhand, Dharwar, Singhbhum (Saha 1994; Halls et al. 2007; Pati et al. 2008). These dykes are disposed in NE-SW, NW-SE direction and they have tholeiitic composition. Many of them bear the signature of low grade metamorphic alteration (Mallikharjuna Rao et al. 2005; Bose 2008).

The mafic dyke swarm, popularly known as the newer dolerite suite, traverses the Precambrian
Singbhum granitic complex in the districts of Singbhum, Keonjhar and Mayurbhanj in eastern India (Dunn 1929; Jones 1934; Krishnan 1936; Dunn and Dey 1942; Saha 1948, 1952; Saha et al. $1972,1973)$. The reticulate dyke system defines two broad populations trending NW-SE and NESW in the Singbhum craton (Dunn 1929; Dunn and Dey 1942; Saha et al. 1973; Bose 2008). These orientations of the dykes apparently imply a principal axis of stress from the north resulting in brittle deformation of the rigid Singbhum pluton (Dunn and Dey 1942). The dykes in the northern domain of the Singbhum pluton appear to be emplaced along planes of conjugate shear fractures

Keywords. Newer dolerite; hydrothermal activity; alteration; subduction. 
(Dunn and Dey 1942; Saha 1994; Mukhopadhyay 2001). It has been proposed that hybrid fracturing of the rigid granitic mass evolved through both extension and shear embracing nucleation, propagation and coalescence at varying relative rates (Mandal et al. 2006). Few radiometric age data are available for these mafic dykes using $\mathrm{K}-\mathrm{Ar}, \mathrm{Rb}-\mathrm{Sr}$, Sm-Nd system of dating (Saha 1994; Mallick and Sarkar 1994) which broadly assign a Proterozoic status to these mafic dykes. It appears from previous works that the newer dolerites were evolved in arc-back arc setting (Bose 2008; Mir et al. 2010, 2013).

The present research comprises field, petrographical and geochemical study of the newer dolerite dykes around Keonjhar of Orissa situated in the western marginal parts of the Singbhum craton respectively (figure 1). The newer dolerite dykes occur as distinct long ridges, hillocks and also as stony wastes dominantly showing a NE-SW, NW-SE and NNE-SSW trend within the Singbhum Granite around Keonjhar (figure 1). In all the exposures, rocks are very hard, compact and massive. The widths of the dykes vary from a few meters to over $1 \mathrm{~km}$. The mafic dykes of the present study show the effect of hydrothermal alteration which imparts a green colour to these rocks causing significant mineralogical changes.

The aim of the present research is to characterize and document the mineralogical changes of the newer dolerite dykes due to hydrothermal activity and to understand the mechanism of such alteration processes which involve addition and subtraction of certain elements,

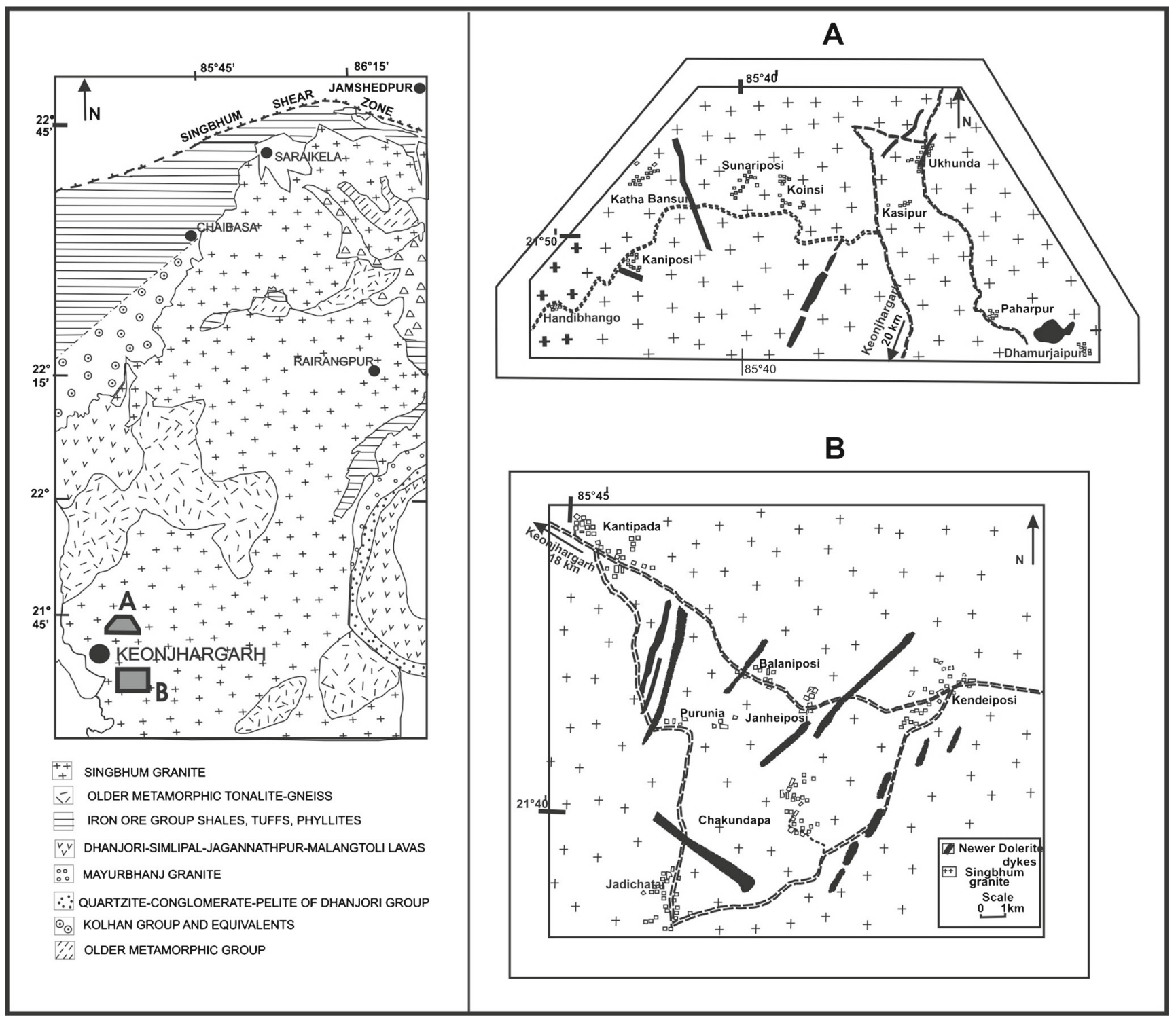

Figure 1. Geological map of Singhbhum region (modified after Saha 1994) indicating study areas denoted by solid blocks A and B around Keonjhar. The two blocks have been blown up to show occurrences of newer dolerite dykes within Singhbhum granite around Keonjhar. Important towns and villages in and around the study areas have also been marked. 
especially trace elements during such hydrothermal activity.

\section{General geology}

The Sinbhum craton is one of the oldest cratonic nuclei of the Indian landmass (Basu et al. 1981; Goswami et al. 1995; Misra et al. 1999; Mandal et al. 2006; Mukherjee et al. 2008). It preserves a complex geological association involved in several episodes of magmatism, sedimentation and orogenies over a protracted period of time in the Archaean (Goswami et al. 1995; Misra et al. 1999; Mukhopadhyay 2001; Roy and Bhattacharya 2012). The Singbhum Granite batholithic complex within Singhbhum craton comprises at least 12 granitic units, which are considered to have been emplaced in three successive but closely related phases: Phase I, Phase II and Phase III (Saha 1994). The Singhbhum granite pluton is invaded by a group of dykes, the 'Newer Dolerites' as reported by Dunn and Dey (1942) marking the stabilisation of the craton as a whole. The chronostratigraphic succession of rocks of Singhbhum craton (Misra 2006) indicate that the newer dolerite dykes are the youngest mafic magmatic unit.

\section{Petrography and mineralogy}

Petrographic studies were carried out with Nikon Polarizing microscope (Model no. 064333) at the Department of Geology, Presidency University, Kolkata and composition of constituent minerals were determined from diamond polished thin section with carbon coating by Electron Probe Micro Analyses (EPMA) in the laboratory of Geological Survey of India, Kolkata using CAMECA SX 100 with accelerating voltage $15 \mathrm{kV}, 12 \mathrm{nA}$ current and a beam size of 1 micron. All natural standards are used for analyses of $\mathrm{Ca}, \mathrm{Fe}, \mathrm{Si}, \mathrm{Al}, \mathrm{Na}, \mathrm{Mg}, \mathrm{Cr}$, $\mathrm{K}, \mathrm{Ni}, \mathrm{P}$ elements. For analyses of $\mathrm{Mn}$ and $\mathrm{Ti}$, synthetic mineral standard has been used.

Mafic dykes of the study area are represented by both fine-grained porphyritic variety and medium to coarse-grained nonporphyritic variety. Porphyritic varieties are characterized by occurrence of phenocrysts of clinopyroxene and plagioclase. Clinopyroxenes show a faint pink to green colour and occur as single prismatic grains and as clusters. Compositionally they show a wide range of variations from $\mathrm{Wo}_{43.9} \mathrm{En}_{44.3} \mathrm{Fs}_{11.8}$ to $\mathrm{Wo}_{13.9} \mathrm{En}_{27.7} \mathrm{Fs}_{58.4}$ (table 1) forming augite, subcalcic augite, ferroaugite to pigeonite (figure 2). Zoning is observed in some large clinopyroxene grains commonly showing iron enrichment trend from core to rim. In few cases, the augite core of a grain is surrounded by a pigeonite rim. In some dykes, clinopyroxenes are replaced by chlorite, tremolite and actinolitic amphibole (figure 3). In the terminology of Leake et al. (1997), all the studied amphiboles are of calcic type, namely ferro actinolite, actinolite, actinolytic hornblende (figure 4). Orthopyroxene occurs as a major mineral in some dykes but is mostly replaced by bastite leaving a few relict grains (figure 5) (table 1). Dykes with orthopyroxenes are sometimes associated with anorthitic plagioclase $\left(\mathrm{An}_{86.7}\right)$. These orthopyroxene bearing dykes may be classified as norite or noritic gabbro. Fresh plagioclase grains are very rare in the dolerites of the present study area. They are mostly clouded showing dark to light grey coloured dusty appearance (figure 6) and are nearly isotropic between crossed polars. Wide variation of composition (from $\mathrm{An}_{95.3}$ to $\mathrm{Ab}_{99.5}$; table 2) is observed in different parts of unzoned clouded plagioclase grains. Alterations like saussuritization and sericitization are also observed in some plagioclase grains. Unclouded small grains of plagioclase show extreme albitic $\left(\mathrm{Ab}_{97.4}\right)$ compositions with some intermediate ones $\left(\begin{array}{lll}\mathrm{Ab}_{48} & \mathrm{An}_{51.8}\end{array}\right)$ (table 2). Figure 7 shows the variable compositions of both clouded and unclouded plagioclase grains covering a wide range of compositions from albite to anorthite. The common accessory minerals are magnetite, occasionally associated with ilmenite, biotite and sphene. Interstitial quartz and high modal abundance of granophyric intergrowth are commonly developed and often constitute a significant proportion of the rock.

\section{Geochemistry}

In order to get an idea about petrogenetic process and subsequent alteration, chemica composition of mafic rocks appear to be important. For this purpose 37 samples of newer dolerite of the present study have been analyzed to determine major element abundances by XRF method from Wadia Institute of Himalayan Geology, Dehradun, India. Trace elements including rare earth element abundances of 13 samples were determined by inductively coupled plasma mass spectrometry techniques using Perkin Elmer, Sciex ELAN DRC II system at National Geophysical Research Institute, Hyderabad, India. International rock standards like BHVO-1, BR (major elements) and JB2 (trace and REE) were run along with the samples to check the precision and accuracy of measurement. The analyzed and certified values of BHVO-1 and JB2 are given in tables 3 and 4 . The major oxides of these 37 samples show a wide range of compositional varaiation; $\mathrm{SiO}_{2}$ content (46.77-56.99\%), $\quad \mathrm{TiO}_{2} \quad(0.39-2.65 \%)$, $\mathrm{Al}_{2} \mathrm{O}_{3}$ (7.48-14.04\%), FeO (7.51-13.04\%), $\mathrm{Fe}_{2} \mathrm{O}_{3}$ 
Table 1. Representative EPMA data of pyroxene grains in newer dolerite dykes of Keonjhar.

\begin{tabular}{|c|c|c|c|c|c|c|c|c|c|c|c|c|c|c|}
\hline $\begin{array}{l}\text { Sl. no. } \\
\text { Des }\end{array}$ & $\begin{array}{c}1 \\
\text { Cpx }\end{array}$ & $\begin{array}{c}2 \\
\text { Cpx }\end{array}$ & $\begin{array}{c}3 \\
\mathrm{Cpx}\end{array}$ & $\begin{array}{c}4 \\
\mathrm{Cpx}\end{array}$ & $\begin{array}{c}5 \\
\text { Cpx }\end{array}$ & $\begin{array}{c}6 \\
\text { Cpx core }\end{array}$ & $\begin{array}{cc}7 & \\
\operatorname{rim} & \mathrm{F}\end{array}$ & $\begin{array}{c}8 \\
\text { Relict opx }\end{array}$ & $\begin{array}{c}9 \\
\text { Pig }\end{array}$ & $\begin{array}{c}10 \\
\text { Cpx }\end{array}$ & $\begin{array}{c}11 \\
\text { Cpx }\end{array}$ & $\begin{array}{c}13 \\
\text { Cpx }\end{array}$ & $\begin{array}{c}14 \\
\text { Cpx }\end{array}$ & $\begin{array}{c}16 \\
\text { Relict opx }\end{array}$ \\
\hline $\mathrm{O}_{2}$ & 49.96 & 51.9 & 50.89 & 51.31 & 49.41 & 50.43 & 51.34 & 54.62 & 51.17 & 49.76 & 52.16 & 50.29 & 49.33 & 54.68 \\
\hline $\mathrm{TiO}_{2}$ & 1.1 & 0.22 & 0.22 & 0.04 & 0.73 & 0.56 & 0.24 & 0.06 & 2.88 & 0.67 & 0.39 & 0.38 & 0.56 & 0.11 \\
\hline $\mathrm{Al}_{2} \mathrm{O}_{3}$ & 2.79 & 1.62 & 2.94 & 1.89 & 2.04 & 1.8 & 1.29 & 1.14 & 0.82 & 1.7 & 2.08 & 2.18 & 0.93 & 1.49 \\
\hline $\mathrm{FeO}$ & 12.35 & 9.65 & 7.01 & 20.02 & 16.5 & 12.37 & 18.45 & 13.21 & 26.12 & 19.63 & 8.6 & 14.57 & 28.62 & 12.1 \\
\hline $\mathrm{Cr}_{2} \mathrm{O}_{3}$ & 0 & 0.04 & 0.85 & 0.1 & 0.08 & 0 & 0.13 & 0.4 & 0 & 0 & 0 & 0.19 & 0 & 0.5 \\
\hline $\mathrm{MnO}$ & 0.23 & 0.24 & 0.27 & 0.18 & 0.4 & 0.21 & 0.43 & 0.21 & 0.29 & 0.42 & 0.21 & 0.27 & 0.51 & 0.2 \\
\hline $\mathrm{MgO}$ & 13.9 & 16.49 & 15.36 & 11.41 & 12.83 & 15.93 & 21.19 & 28.15 & 7.04 & 11.25 & 16.68 & 15.91 & 12.05 & 28.08 \\
\hline $\mathrm{CaO}$ & 19.17 & 18.55 & 21.2 & 12.68 & 17.55 & 17.77 & 5.84 & 2.34 & 4.89 & 16.29 & 19.25 & 15.07 & 7.63 & 2.37 \\
\hline $\mathrm{Na}_{2} \mathrm{O}$ & 0.33 & 0.19 & 0.35 & 0.29 & 0.28 & 0.31 & 0.12 & 0.02 & 3.62 & 0.23 & 0.22 & 0.24 & 0.11 & 0.01 \\
\hline $\mathrm{K}_{2} \mathrm{O}$ & 0.02 & 0 & 0 & 0.07 & 0 & 0 & 0.02 & 0.06 & 0.95 & 0 & 0.02 & 0 & 0 & 0.01 \\
\hline \multicolumn{15}{|c|}{ Number of ions on the basis of 6 oxygen } \\
\hline $\mathrm{Si}$ & 1.876 & 1.938 & 1.892 & 2.016 & 1.882 & 1.887 & 1.919 & 1.948 & 2.04 & 1.919 & 1.928 & 1.897 & 1.943 & 1.959 \\
\hline $\mathrm{Al}$ & 0.053 & 0.062 & 0.128 & 0.087 & 0.819 & 0.079 & 0.057 & 0.048 & 0.038 & 0.077 & 0.098 & 0.097 & 0.043 & 0.0625 \\
\hline $\mathrm{Fe}^{3+}$ & 0.087 & 0.052 & 0.074 & 0 & 0.122 & 0.136 & 0.099 & 0.045 & 0.038 & 0.063 & 0.048 & 0.099 & 0.046 & 0 \\
\hline $\mathrm{Ti}$ & 0.031 & 0.006 & 0.006 & 0.001 & 0.021 & 0.016 & 0.007 & 0.002 & 0.086 & 0.019 & 0.011 & 0.011 & 0.017 & 0.003 \\
\hline $\mathrm{Fe}^{2+}$ & 0.3 & 0.249 & 0.144 & 0.658 & 0.404 & 0.25 & 0.478 & 0.349 & 0.833 & 0.571 & 0.217 & 0.361 & 0.897 & 0.363 \\
\hline $\mathrm{Cr}$ & 0 & 0.001 & 0.025 & 0.003 & 0.002 & 0 & 0.004 & 0.011 & 0 & 0 & 0 & 0.006 & 0 & 0.014 \\
\hline $\mathrm{Mg}$ & 0.778 & 0.918 & 0.851 & 0.668 & 0.728 & 0.889 & 1.181 & 1.497 & 0.418 & 0.647 & 0.919 & 0.895 & 0.707 & 1. \\
\hline Mn & 0.007 & 0.008 & 0.009 & 0.006 & 0.013 & 0.007 & 0.014 & 0.0 & 0.01 & 0.014 & 0.007 & 0.009 & 0.017 & 0.006 \\
\hline $\mathrm{Ca}$ & 0.771 & 0.742 & 0.845 & 0.534 & 0.716 & 0.713 & 0.234 & 0.089 & 0.209 & 0.673 & 0.762 & 0.609 & 0.322 & 0.091 \\
\hline $\mathrm{Na}$ & 0.024 & 0.014 & 0.025 & 0.022 & 0.021 & 0.022 & 0.009 & 0.001 & 0.28 & 0.017 & 0.016 & 0.018 & 0.008 & 0.001 \\
\hline $\mathrm{K}$ & 0.001 & 0 & 0 & 0.004 & 0 & 0 & 0.001 & 0.003 & 0.048 & 0 & 0.001 & 0 & 0 & 0 \\
\hline Wo & 39.66 & 31.09 & 43.93 & 28.61 & 36.11 & 35.71 & 11.67 & 4.00 & 13.85 & 34.23 & 39.02 & 30.89 & 16.19 & 4.64 \\
\hline En & 40.02 & 46.62 & 44.29 & 35.82 & 36.73 & 44.55 & 58.89 & 75.35 & 27.75 & 32.89 & 47.04 & 45.37 & 35.57 & 76.54 \\
\hline Fs & 20.32 & 15.69 & 11.78 & 35.58 & 27.15 & 19.74 & 29.44 & 20.15 & 58.40 & 32.89 & 13.94 & 23.75 & 48.25 & 18.81 \\
\hline
\end{tabular}

Des: description, Cpx: Clinopyroxene, Opx: orthopyroxene, Pig: pigeonite.

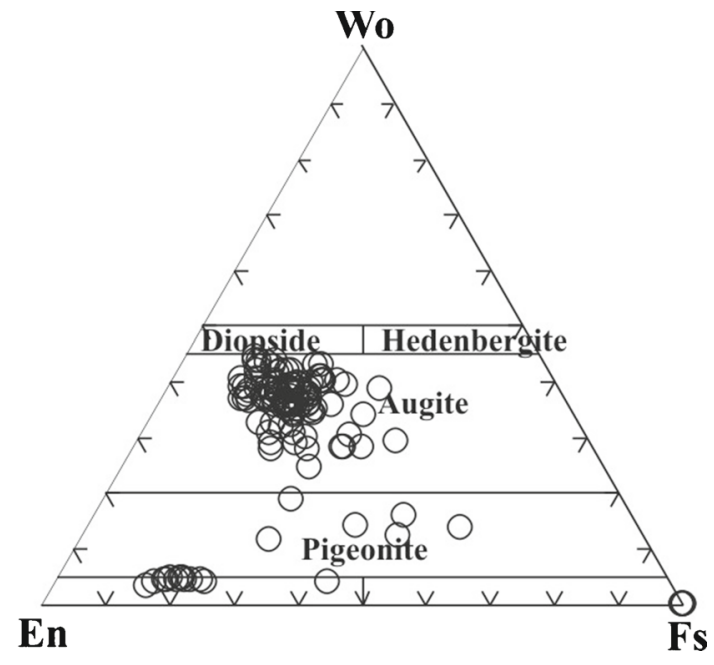

Figure 2. Representative compositions of pyroxenes in newer dolerite dykes of Keonjhar area.

(1.46-2.53\%), $\mathrm{MgO}(3.19-14.07 \%), \mathrm{MnO}(0.14-$ $0.23 \%), \mathrm{Na}_{2} \mathrm{O}(1.11-4.34 \%), \mathrm{K}_{2} \mathrm{O}(0.43-1.72 \%)$, and $\mathrm{P}_{2} \mathrm{O}_{5}$ (0.06-0.58\%). The dolerites are basalt to basaltic andesite in composition (figure 8). A prominent iron-enrichment trend is observed in the AFM diagram (figure 9).

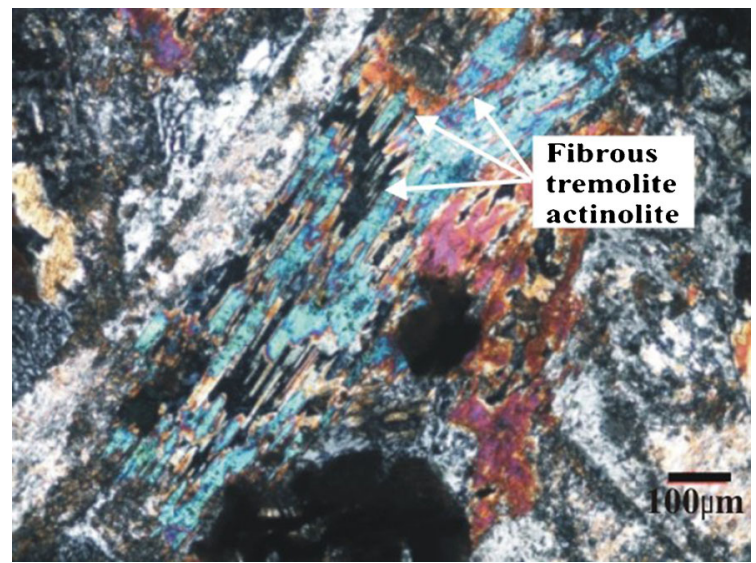

Figure 3. Photomicrograph showing replacement of clinopyroxene grain by tremolite-actinolite needles between crossed polars.

In a majority of bivariate diagrams with $\mathrm{mg}$ number against $\mathrm{TiO}_{2}, \mathrm{FeO}, \mathrm{Na}_{2} \mathrm{O}+\mathrm{K}_{2} \mathrm{O}, \mathrm{P}_{2} \mathrm{O}_{5}$ (figure 10), a distinct linear differentiation trend is observed supporting the co-genetic nature of the dolerite dykes. Inter element correlation and variation is an important aspect to portray magmatic differentiation mechanism. It is observed 


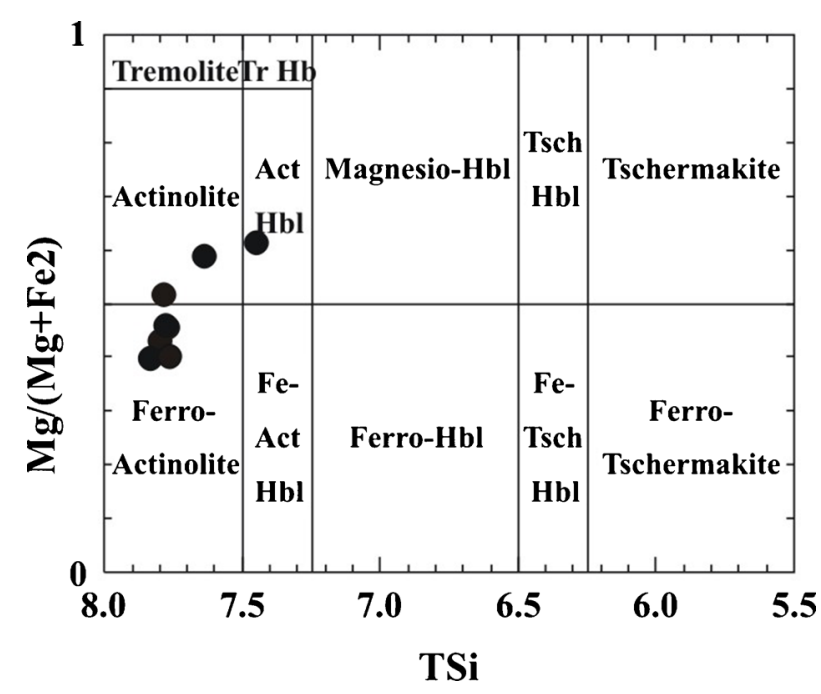

Figure 4. Representative compositions of amphiboles in newer dolerite dykes of Keonjhar area.

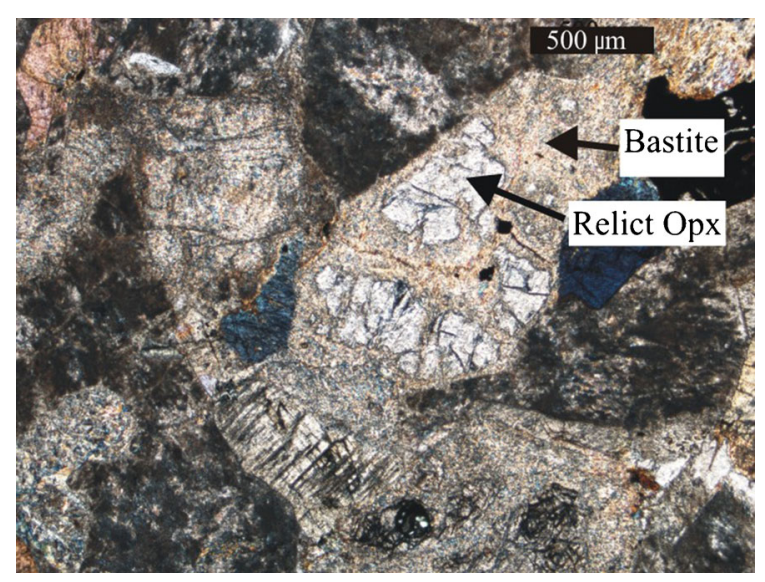

Figure 5. Photomicrograph showing bastitised orthopyroxene grain with some relict parts in plane polarized light.

that $\mathrm{TiO}_{2}, \mathrm{FeO},\left(\mathrm{Na}_{2} \mathrm{O}+\mathrm{K}_{2} \mathrm{O}\right), \mathrm{P}_{2} \mathrm{O}_{5}$ show a good negative correlation with $\mathrm{mg}$ number whereas oxides such as $\mathrm{TiO}_{2}, \mathrm{FeO}, \mathrm{P}_{2} \mathrm{O}_{5}$ show a positive correlation. $\mathrm{K}_{2} \mathrm{O} / \mathrm{TiO}_{2}$ ratio shows a positive correlation with mg number. Absence of good correlation is observed in $\mathrm{CaO}$ vs. $\mathrm{MgO}$ and $\mathrm{SiO}_{2}$ vs. $\mathrm{MgO}$.

Binary variation diagrams constructed with some important trace elements like $\mathrm{Ba}, \mathrm{Y}, \mathrm{Ni}$, Th, $\mathrm{Zr}, \mathrm{Nb}$, La, etc., clearly demonstrate the co-genetic nature of the dolerite dykes (figure 11). In all the plots, the different dykes show a distinct trend of evolution except $\mathrm{Rb}-\mathrm{Y}$. Rb is highly sensitive to alteration and as a result does not show any correlation with Y. A good positive correlation is observed between $\mathrm{Ba}-\mathrm{Y}$, Th-Y, $\mathrm{Zr}-\mathrm{Nb}$, $\mathrm{La}-\mathrm{Zr}$ while a negative correlation is found in case of $\mathrm{Ni}-\mathrm{Zr}$.

REE abundances of mafic dykes of the present study are plotted in a chondrite-normalized diagram (figure 12). The plots of the newer dolerite suite show a fractionated REE pattern with LREE enrichment. All the dykes show a similar pattern but their overall abundances vary from 50 to 100 times higher compared to chondrite. Similar REE pattern of the dolerite dykes also supports their co-genetic nature.

\section{Signatures of alteration from petrographic and geochemical studies}

\subsection{Petrographical features}

We will discuss some of the typical alteration features of some minerals which may throw light on the possible alteration processes which operated during the formation of these rocks.

\subsubsection{Clouding in feldspar}

Detailed observation of thin sections revealed that plagioclase feldspar laths under plane polarized light, commonly show grey to black turbid patchy discolouration or clouding (figure 6). This clouding occurs due to presence of ultramicroscopic dust like inclusions (MacGregor 1931; Poldervanrt and Gilkey 1954; Pichamuthu 1959; Zhang 1988; Halls et al. 1994). Previous works on clouded plagioclase (Knopf and Jonas 1929) show that these dusty inclusions are mostly magnetite, i.e., much of the iron in clouded feldspar is in the divalent state.

Spatial distribution of clouding is variable among different grains in a specimen and among different specimens in the study area. But an overall account shows that many of the rocks show intense clouding in plagioclase while others show medium to weak clouding effects. The optical density varies across a grain. The outer margin is sometimes clearer than the interior because it contains no inclusions. Feldspar clouding is easily distinguishable from feldspar saussuritization. Feldspar clouding forms a brown to dark grey stain in plane polarized light, formed by the presence of sub-microscopic magnetite. Between crossed polars these clouded grains appear opaque. Saussurite forms a dusty grey amalgamation of visible minerals in plane polarized light, with a speckled appearance between cross nicols.

Previous observation revealed that clouded feldspar is very common in mafic dykes that transect Proterozoic shield areas such as satellite dykes of the Great Dyke in Zimbabwe (Robertson and Van Breeman 1970), Matachewan dykes of the Canadian shield (Halls and Palmer 1990), dykes on Wyoming shield, USA (Armbrustmacher and Banks 1974), Dharwar craton in India (Pichamuthu 1959) and many others. It has been 


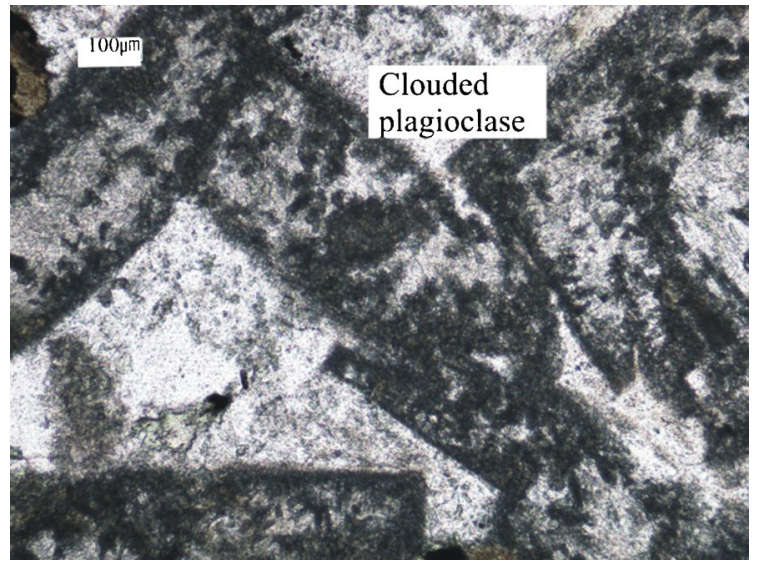

Figure 6. Photomicrograph showing clouded plagioclase grain in plane polarized light.

shown that cloudiness is a product of thermal metamorphism caused by regional heating or by the heat of neighbouring igneous magma (MacGregor 1931). We prefer the regional heating model of thermal metamorphism as the possible cause for feldspar clouding in our study area as there is no evidence of intrusive rocks in the vicinity. It is also evident from petrographic studies that the dolerite dykes of the present study area have suffered hydrothermal alteration.
Among many hypotheses, we consider the model of Poldervanrt and Gilkey (1954) suitable to explain the clouding of feldspar of the study area. According to the hypothesis, weak clouding may result from exsolution of iron incorporated into the feldspar during growth, but intense clouding is produced by diffusion of material into the feldspar after growth by means of channels produced by unmixing of plagioclase into regions of albite and anorthite. The clouded feldspar of the newer dolerites around Keonjhar shows extreme compositional variation $\left(\mathrm{Ab}_{4.7}\right.$ to $\mathrm{Ab}_{99.5}$; table 2) within a single grain. This variation is considered the result of unmixing of plagioclase of intermediate composition. Such unmixing might have occurred when the plagioclase was held at high temperatures for a long time in the presence of water. Such conditions occur during metamorphism of basic rocks of high iron content and from entrance of Fe-rich solutions along the zones of unmixing precipitating submicroscopic grains of iron mineral (Poldervanrt and Gilkey 1954).

\subsubsection{Large bastitised orthopyroxene grain}

Some of the dykes contain numerous large bastitised orthopyroxene (figure 5) grains leaving relict

Table 2. Representative EPMA data of plagioclase grains in newer dolerite dykes of Keonjhar.

\begin{tabular}{|c|c|c|c|c|c|c|c|c|}
\hline $\begin{array}{l}\text { Sl. no. } \\
\text { Des. }\end{array}$ & $\begin{array}{c}1 \\
\text { Plag }\end{array}$ & $\begin{array}{c}2 \\
\text { Plag }\end{array}$ & $\begin{array}{c}3 \\
\text { Plag }\end{array}$ & $\begin{array}{c}4 \\
\text { Plag }\end{array}$ & $\begin{array}{c}5 \\
\text { Relict plag }\end{array}$ & $\begin{array}{c}6 \\
\text { Plag core }\end{array}$ & $\begin{array}{c}7 \\
\text { Cloudy plag }\end{array}$ & $\begin{array}{c}8 \\
\text { Cloudy plag }\end{array}$ \\
\hline $\mathrm{SiO}_{2}$ & 60.9 & 64.56 & 58.87 & 56.45 & 58.37 & 65.85 & 68.36 & 48.87 \\
\hline $\mathrm{TiO}_{2}$ & 0.11 & 0.07 & 0.04 & 0.16 & 0 & 0.12 & 0 & 0 \\
\hline $\mathrm{Al}_{2} \mathrm{O}_{3}$ & 23.11 & 20.89 & 23.75 & 25.37 & 25.07 & 17.73 & 19.29 & 25.57 \\
\hline $\mathrm{FeO}$ & 0.53 & 0.26 & 0.56 & 0.59 & 1.06 & 1.7 & 0.14 & 4.13 \\
\hline $\mathrm{MnO}$ & 0.05 & 0.04 & 0 & 0.03 & 0 & 0.04 & 0 & 0.05 \\
\hline $\mathrm{MgO}$ & 0.01 & 0 & 0.05 & 0.03 & 0.39 & 1.08 & 0.04 & 0.36 \\
\hline $\mathrm{CaO}$ & 5.14 & 2.59 & 7.35 & 8.92 & 5.16 & 1.26 & 0.08 & 13.04 \\
\hline $\mathrm{Na}_{2} \mathrm{O}$ & 8.1 & 9.64 & 7 & 6.12 & 6.99 & 10.57 & 11.61 & 4.07 \\
\hline $\mathrm{Cr}_{2} \mathrm{O}_{3}$ & 0 & 0.03 & 0.06 & 0 & 0.02 & 0 & 0.05 & 0 \\
\hline $\mathrm{K}_{2} \mathrm{O}$ & 0.78 & 0.62 & 0.73 & 0.55 & 2.11 & 0.23 & 0.08 & 1.72 \\
\hline \multicolumn{9}{|c|}{ Cations on the basis of 16 oxygen } \\
\hline $\mathrm{Si}$ & 5.529 & 5.792 & 5.423 & 5.231 & 5.313 & 6.074 & 6.005 & 4.95 \\
\hline $\mathrm{Al}$ & 2.471 & 2.207 & 2.577 & 2.769 & 2.687 & 1.926 & 1.995 & 3.05 \\
\hline $\mathrm{Ti}$ & 0 & 0.01 & 0 & 0 & 0 & 0.008 & 0 & 0 \\
\hline $\mathrm{Fe}^{2}$ & 0.01 & 0.056 & 0.065 & 0.022 & 0.106 & 0.04 & 1.008 & 0.07 \\
\hline $\mathrm{Mg}$ & 0.004 & 0.008 & 0.006 & 0.001 & 0.18 & 0.001 & 0.004 & 0.016 \\
\hline $\mathrm{Ca}$ & 0.047 & 1.02 & 1.43 & 0.479 & 1.24 & 0.5 & 2.917 & 0 \\
\hline $\mathrm{Na}$ & 1.923 & 1.029 & 0.668 & 1.438 & 1.15 & 1.426 & 0.145 & 1.88 \\
\hline K & 0.005 & 0.051 & 0.018 & 0.041 & 0.004 & 0.09 & 0 & 0.009 \\
\hline $\mathrm{Ab}$ & 97.4 & 49.0 & 31.6 & 73.4 & 48.0 & 70.7 & 4.7 & 99.5 \\
\hline An & 2.4 & 48.6 & 67.5 & 24.5 & 51.8 & 24.8 & 95.3 & 0.0 \\
\hline Or & 0.2 & 2.4 & 0.9 & 2.1 & 0.2 & 4.5 & 0.0 & 0.5 \\
\hline
\end{tabular}

Plag: Plagioclase feldspar, Des: description. 


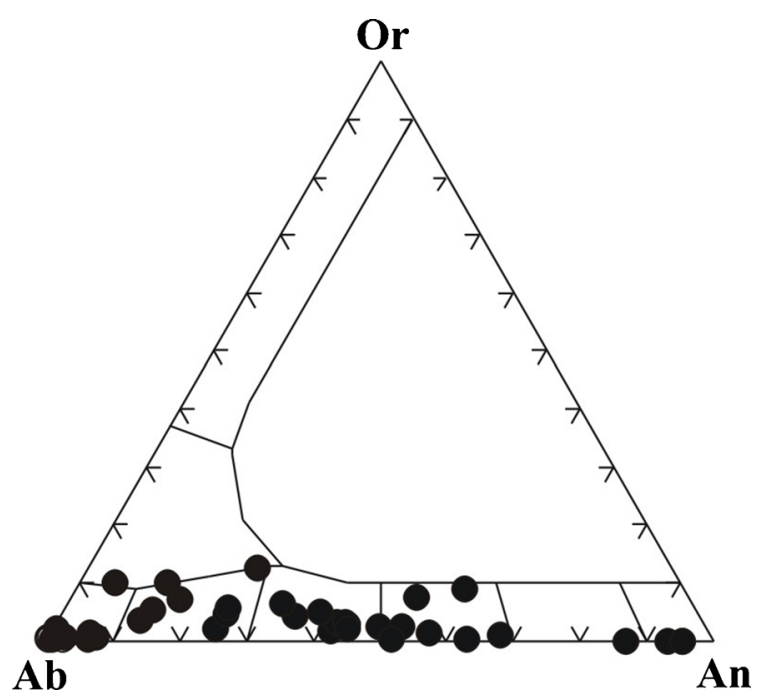

Figure 7. Composition of both clouded and unclouded plagioclase grains in $\mathrm{Ab}-\mathrm{An}-\mathrm{Or}$ diagram.

parts of unaltered orthopyroxenes. The composition of these orthopyroxene grains varies from

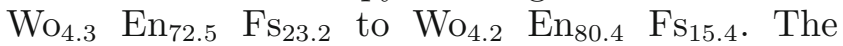
grains are associated with rare augite and plagioclase grains. Bose (2008) has reported presence of partly bastitised orthopyroxene in a norite sample within newer dolerite dykes from Parsola but due to the absence of an interlocking boundary of orthopyroxene grains, Bose (2008) suggested that the rock could be a cumulate. In our study, as the orthopyroxene grains in some of the dykes show interlocking texture with associated plagioclase and clinopyroxenes, it is more likely that they might have been formed by the contamination of the upcoming magma with the granitic country rock (Deer et al. 1997). Similar orthopyroxene bearing dolerite dyke has been reported from Chaibasa area of Singhbhum region (Sengupta and Ray 2012) where co-existence of bastitised orthopyroxenes, anorthitic plagioclase and clinopyroxene has been explained as product of contamination of granitic country rock and mafic melt. In the present study, coexistence of orthopyroxene $\left(\begin{array}{lll}\mathrm{WO}_{3.5} & \mathrm{En}_{82} & \mathrm{Fs}_{14.5}\end{array}\right)$ and anorthitic plagioclase $\left(\mathrm{An}_{93.1}\right)$ possibly suggest similar assimilation and transformation of clinopyroxene to orthopyroxene coupled with migration of $\mathrm{Ca}$ ion into plagioclase during petrogenesis. Formation of bastite in orthopyroxene indicates hydrothermal activity during greenschist facies metamorphism (Johnson et al. 2004; Plumper et al. 2012).

\subsubsection{Actinolite-tremolite assemblage}

In many dykes, fine needles of tremolite and actinolite are observed along marginal parts of clinopyroxene grains (figure 3). In some cases, the clinopyroxene has been altered to fine tremolite and actinolite needles. The presence of a few discrete primary amphibole grains and frequent hydrothermal alteration of clinopyroxene to chlorite and actinolitic amphibole suggest influence of water during late magmatic stage and metamorphic alteration (Devaraju et al. 2008). According to Devaraju et al. (2008), the mafic dyke of Western Dharwar craton has widespread evidence of deuteric alteration. Minerals such as uralite, chlorite, epidote are considered products of the interaction of deuteric liquid with ferromagnesian minerals, pyroxene. The composition of deuteric liquids has been assessed by them as one with high silica, alumina, alkali, Ti, P and REE. The actinolitetremolite assemblage of newer dolerite dykes around Keonjhar may be considered products of interaction of late magmatic hydrous fluid and early magmatic clinopyroxene where the reaction involves migration of volatile phases along with dissolved silica, alkali, REE from hydrothermal fluid to the clinopyroxene grains. Similar alterations of clinopyroxene grains to actinolite, tremolite needles have been recorded from low grade metamorphosed mafic volcanic rocks of the Mira terrane of Avalonia, southeastern Cape Breton Island, Nova Scotia (Mc Mullin et al. 2010).

\section{Changes in chemical composition of the mafic dykes due to alteration}

Ocean floor rocks show a range of consistent mineralogical alterations during low temperature hydrothermal processes (Frey et al. 1974; Mottl 1983). Newer dolerite rocks of the present area also exhibit several mineralogical changes like alteration of clinopyroxenes to tremolite-actinolite needles,bastitization of orthopyroxenes, clouding in feldspars which have been discussed in detail in previous sections. It is obvious that changes of these mineralogical compositions should also be reflected in the chemical composition of the rock; i.e., the altered rocks would show some changes in major and trace element abundances from their fresh counterparts.

Several studies on altered mafic rocks have shown that most, if not all, elements can be added or subtracted from a rock during low temperature ocean floor metamorphism (Mottl and Holland 1978; Seyfried et al. 1988) and the extent of the effect of alteration varies from one member to the other within a group although they show overall similar mineralogical changes. These rocks are particularly effective for such a geochemical study as they show a range of mineralogical 


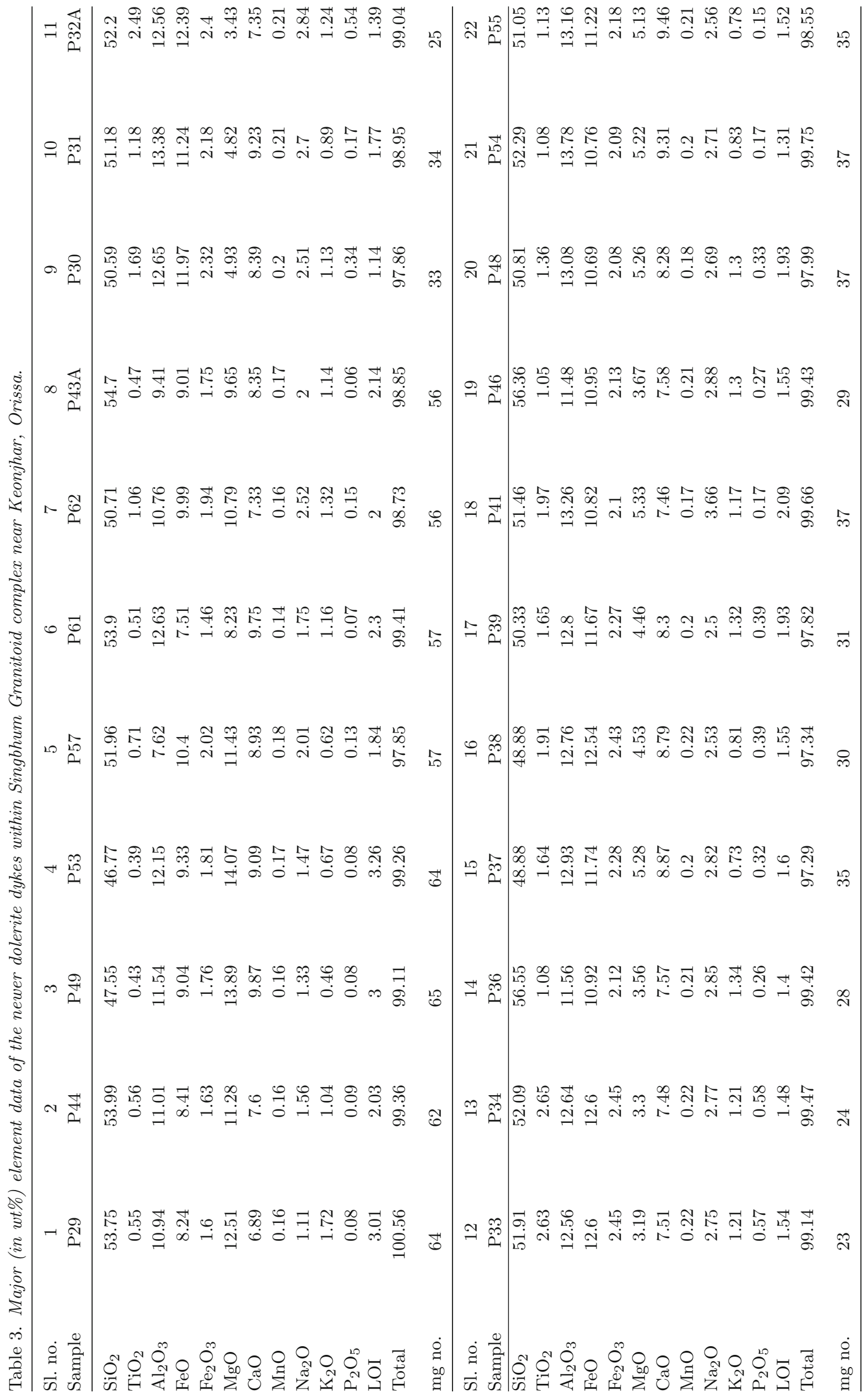




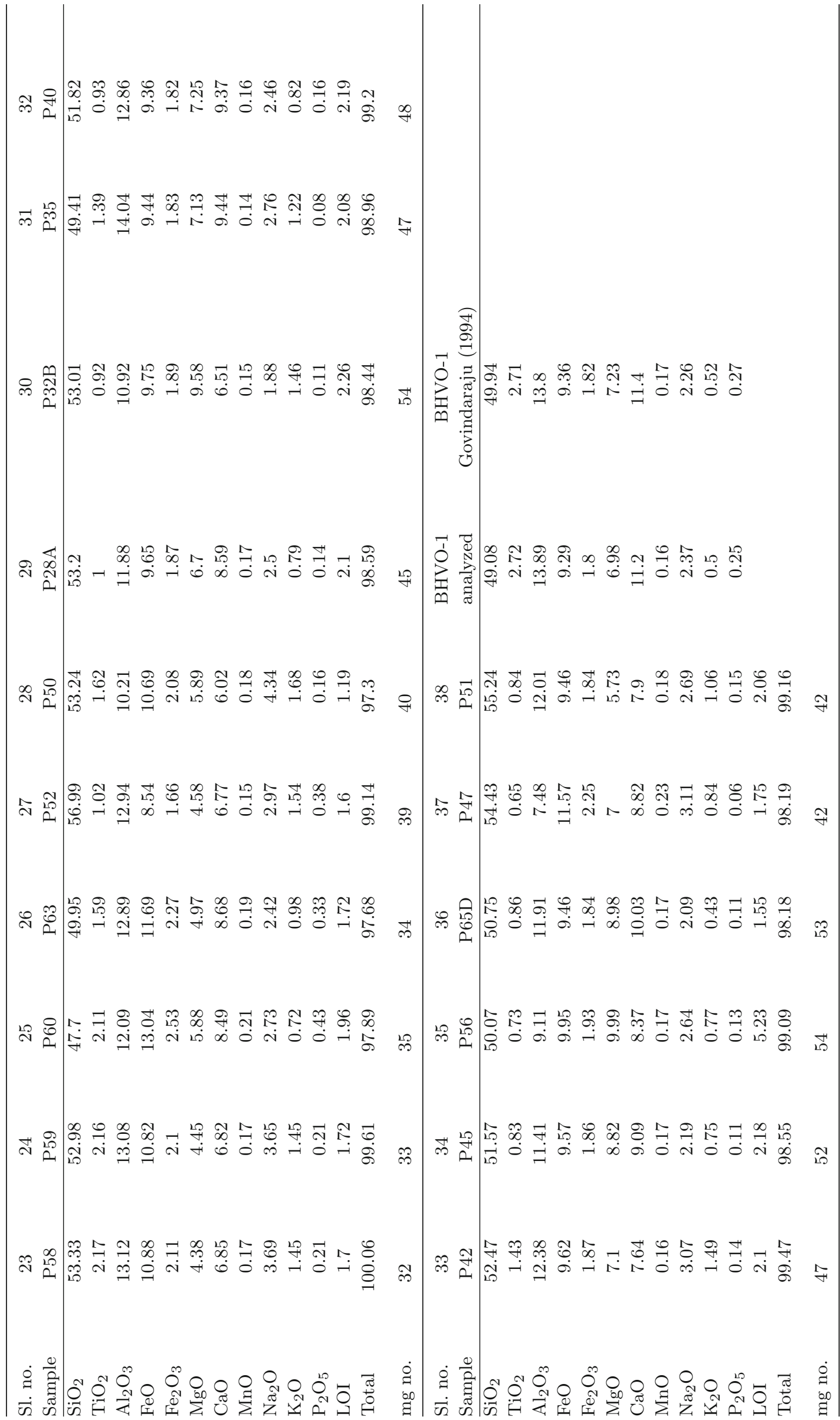




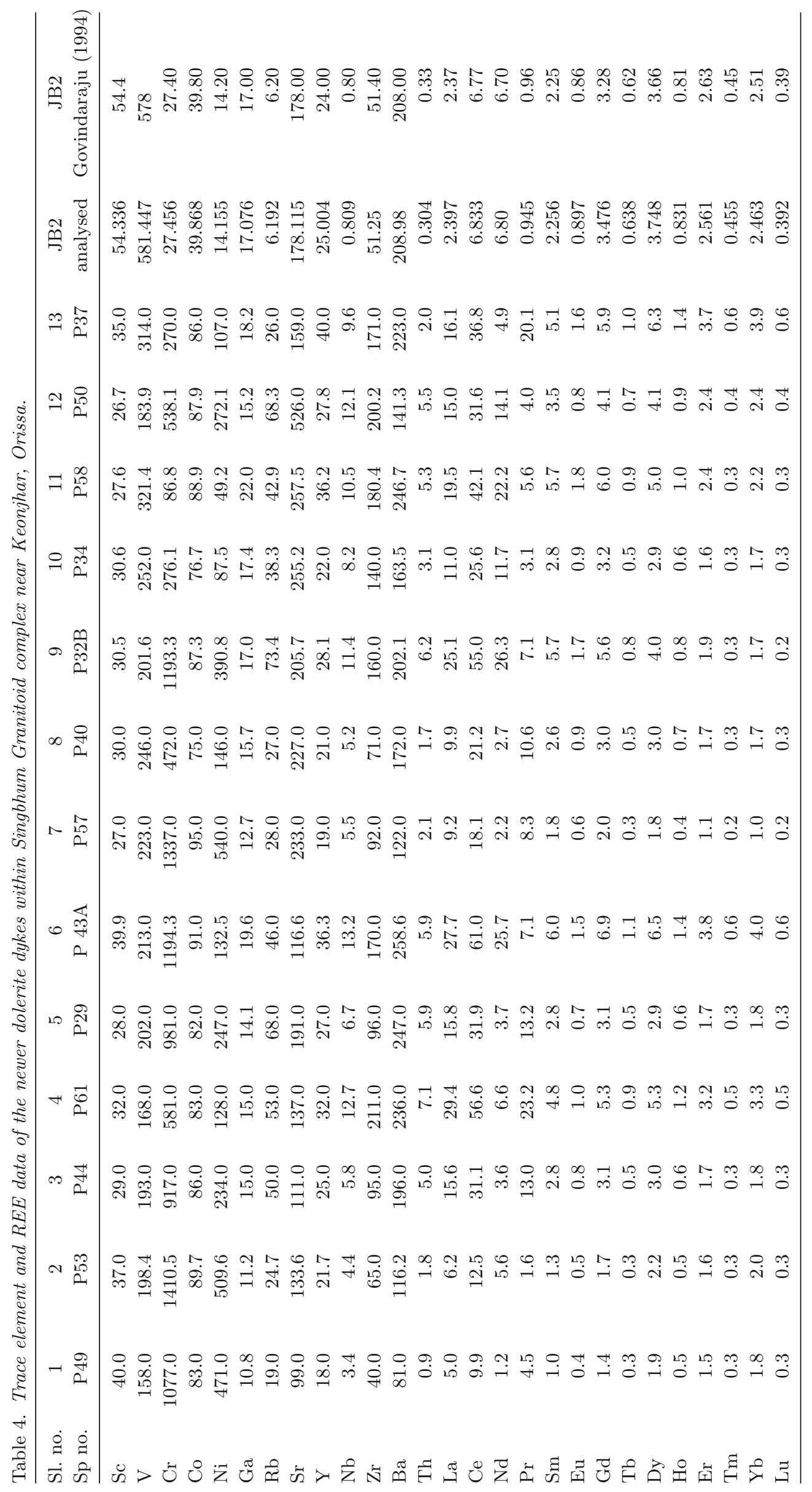




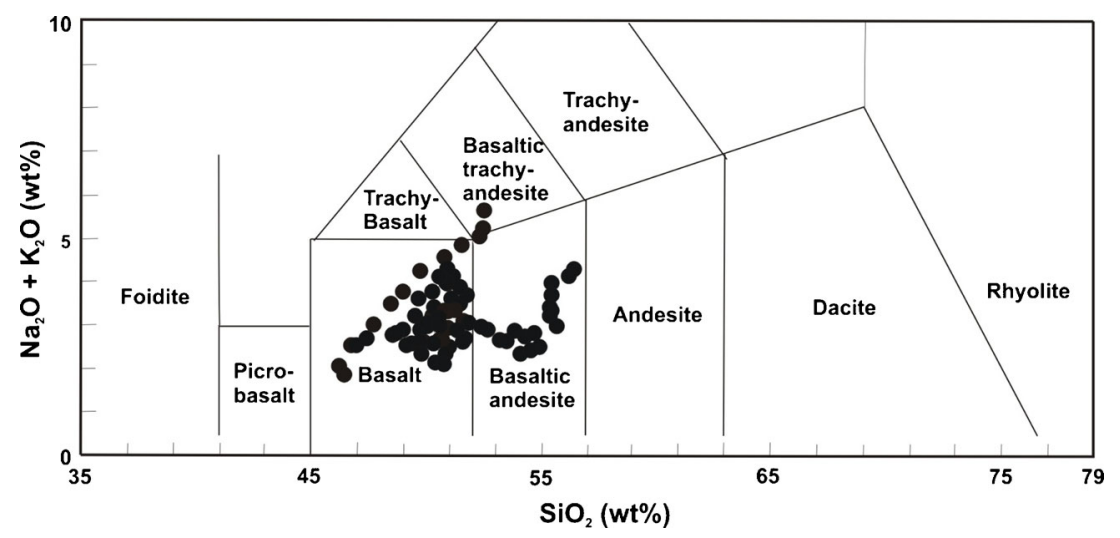

Figure 8. Total alkali silica classification diagram (TAS) for mafic dykes (after Le Bas 2000) showing the plots of newer dolerite dykes of Keonjhar in the field of basalt and basaltic andesite.

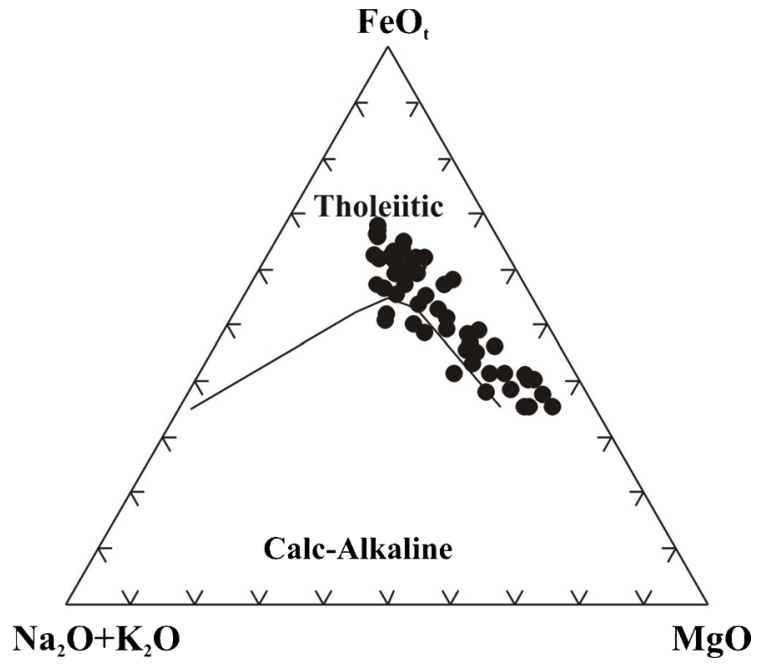

Figure 9. Plots of the newer dolerite dykes of Keonjhar in the AFM diagram (after Irvine and Baragar 1971). The iron enrichment trend can be clearly noted.

alterations. It has been observed that mobile elements like $\mathrm{Ba}, \mathrm{Rb}$, Th, etc., and even some immobile elements as $\mathrm{Nb}$ and $\mathrm{Zr}$ can be affected under specific conditions (Hellman et al. 1979; Hynes 1980). Behaviour of a particular element is dependent on the element concentration in the rock, on its concentration in solutions entering the rock, and on partitioning between the fluid phase and the low-temperature secondary minerals that are stable in the rock (Frey et al. 1974; Mottl 1983).

In order to document quantitatively the effects of alteration on newer dolerites of the study area, we are following the methods adopted by Greenough et al. (1990). In this process, to assess chemical changes caused by alteration, we have compared the least altered dolerite sample of the area with altered samples that had initial compositions similar to those of unaltered rocks. It has been observed, that in case of low temperature alteration of mafic rocks, one of the most obvious effects of alteration is highly variable $\mathrm{Rb}$ values within a group of rocks (Backman et al. 1988). The dolerite rocks of the study area show large variations in concentration of $\mathrm{Rb}$ (19-73.42 ppm) which cannot be accounted for only in terms of differentiation. So, alteration must have played an important role in creating large variations in $\mathrm{Rb}$ content among different dolerite samples. Therefore, we assume that $\mathrm{Rb}$ is an alteration sensitive element and the sample with lowest $\mathrm{Rb}$ value represents the least altered dolerite dyke of the area. Among several established immobile elements like $\mathrm{Zr}, \mathrm{Nb}$, $\mathrm{Y}$, etc., we observe that $\mathrm{Y}$ concentration values show least variation (table 4) among the newer dolerite dykes of our study area. Therefore, to quantify the geochemical effects of alteration of the mafic dykes, we assume that $\mathrm{Y}$ was immobile and use it to evaluate the mobility of all other elements as described below. To assess the mobility of different elements we are using a parameter 'alteration index' of elements which calculates the percentage change between element/Y ratios in altered rocks as compared to least altered rock or fresh rock (i.e., sample with lowest $\mathrm{Rb}$ concentration).

$$
\text { Alteration Index }=\frac{\text { Element } / Y(\text { altered rock })-\text { ElementY }(\text { least altered rock })}{\text { Element } / Y(\text { least altered rock })}
$$



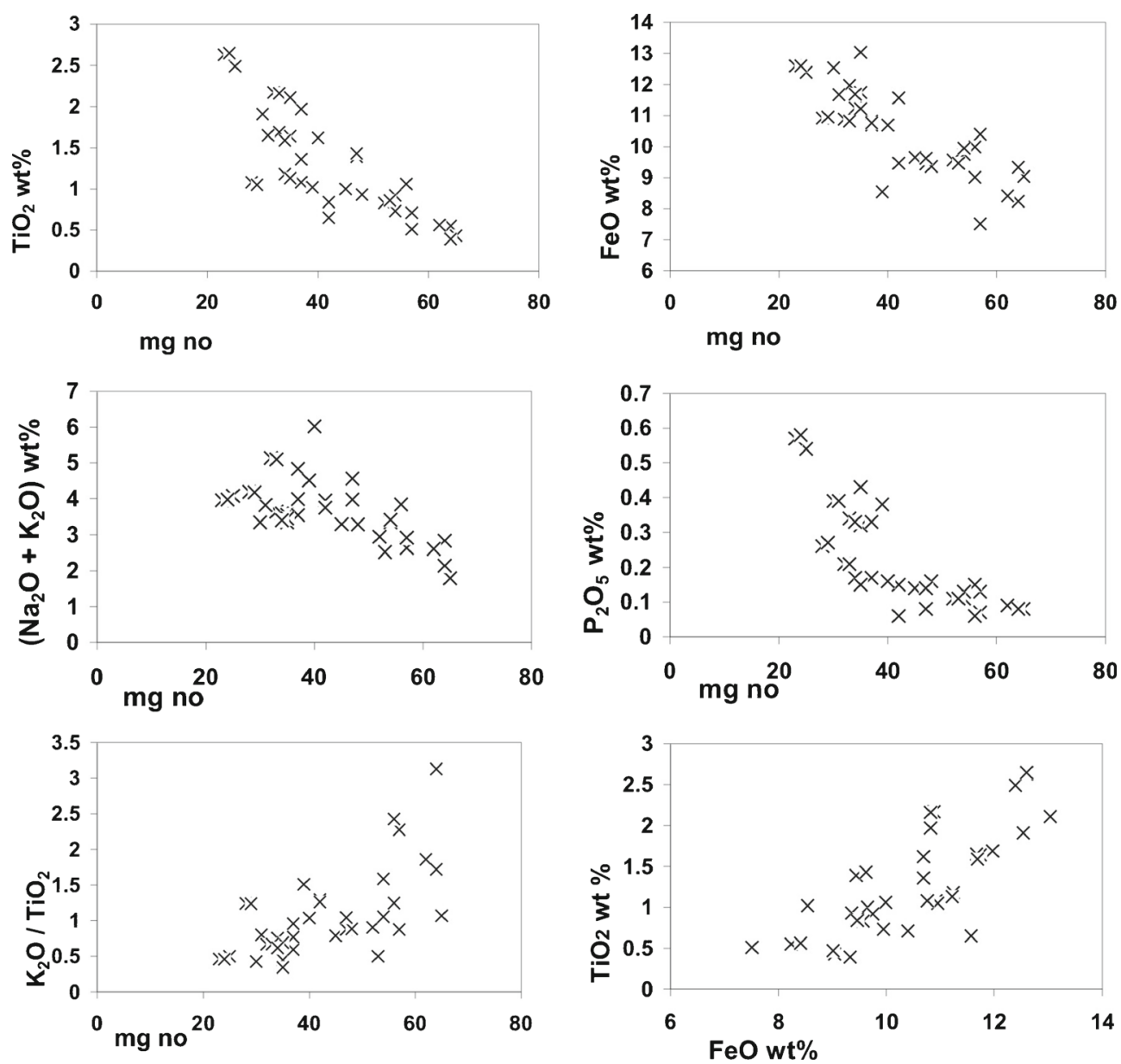

Figure 10. Bivariate diagrams using mg number against major element oxide composition (first five diagrams) and $\mathrm{TiO}_{2}$ vs. $\mathrm{FeO}$ (sixth diagram) of newer dolerite dykes of Keonjhar.

Figure 13(a, b) shows plots of alteration index of different elements ( $\mathrm{Y}$ axis) vs. absolute $\mathrm{Rb}$ concentrations of different altered rocks arranged in ascending order ( $\mathrm{X}$ axis) denoting samples showing a gradual increase in degree of alteration. For a particular $\mathrm{Rb}$ concentration, i.e., a particular altered rock we calculate the alteration index of different elements. Positive values on the $\mathrm{Y}$ axis indicate that an element was added to the rock during alteration process but negative values suggest that the element was removed. The lines denote successive changes of Alteration Index of an element with gradual increase of degree of alteration from least altered sample (i.e., lowest $\mathrm{Rb}$ concentration) to the most altered sample (highest $\mathrm{Rb}$ concentration).

From figure 13(a), it is observed that elements like $\mathrm{Rb}, \mathrm{Ba}, \mathrm{Th}, \mathrm{La}, \mathrm{K}$ show positive values on the $\mathrm{Y}$ axis suggesting that these elements have been added during the alteration process whereas elements like Sc, Cr, Co, Ni, Si, Al, Fe, Mg, Ca show negative values on the $\mathrm{Y}$ axis (figure 13b) implying removal of these elements. The least altered sample of newer dolerite dyke (Rb-19 ppm) occurs in the northern part of the study area and is considered to have localized in the distal part. The degree of alteration increases more or less along southward direction and the most altered sample ( $\mathrm{Rb}-73.42 \mathrm{ppm})$ might represent proximal zone of alteration front (figure 1).

\section{Possible paleotectonic setting}

To get an idea about the tectonic setting of the dolerites we consider several mineralogical and geochemical aspects. As the dolerites show strong effects of hydrothermal alterations as discussed under petrography, it is quite reasonable to rule out the possibility of their emplacement in a continental setting where such alterations are very rare. Formation under an oceanic setting is more likely for the dolerite rocks showing albitisation, bastitisation and other features of hydrothermal alteration. Several workers have suggested a subduction zone related origin of these newer dolerite dykes 

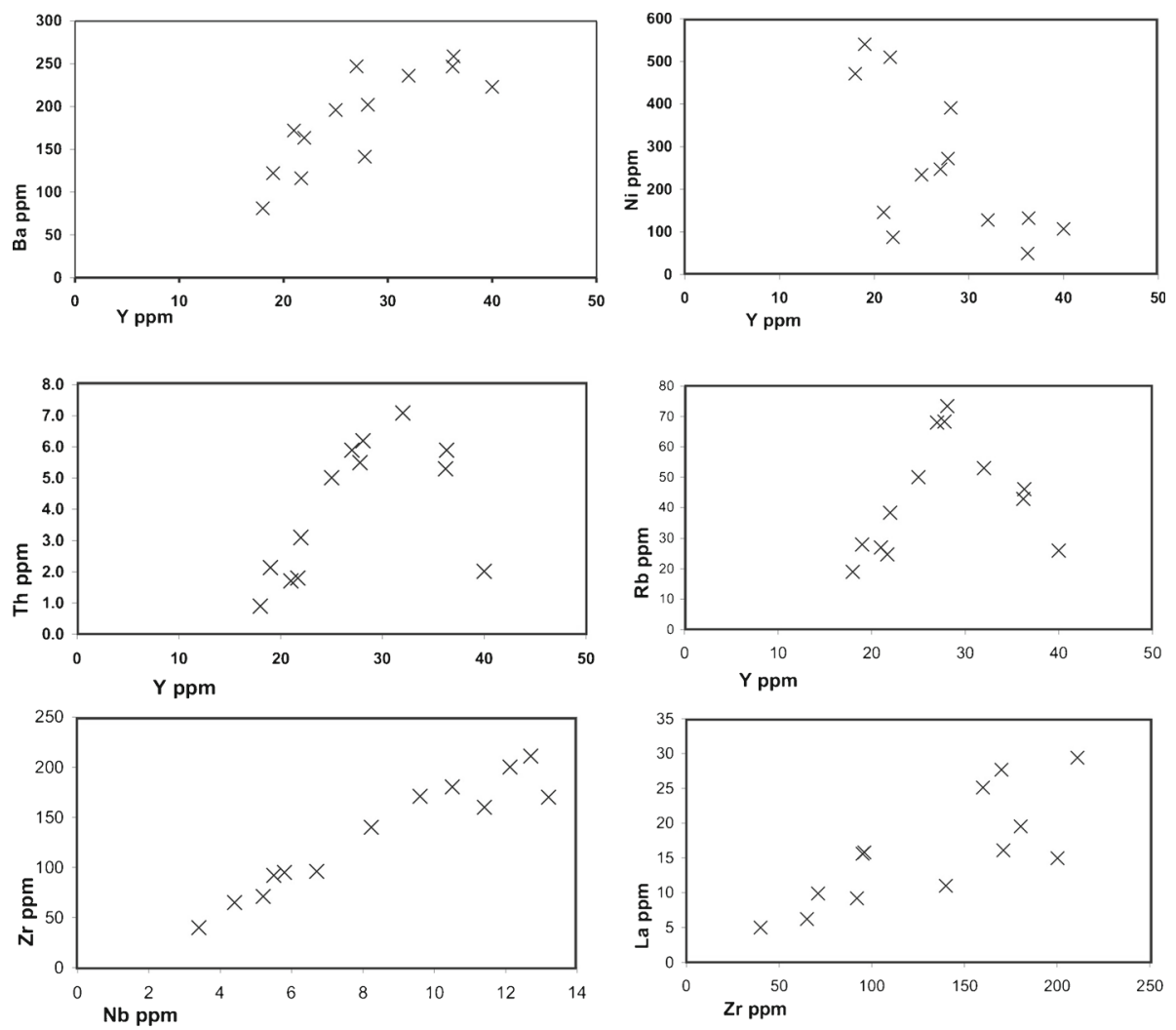

Figure 11. Binary variation diagrams constructed with some important trace element abundances of newer dolerite dykes of Keonjhar.

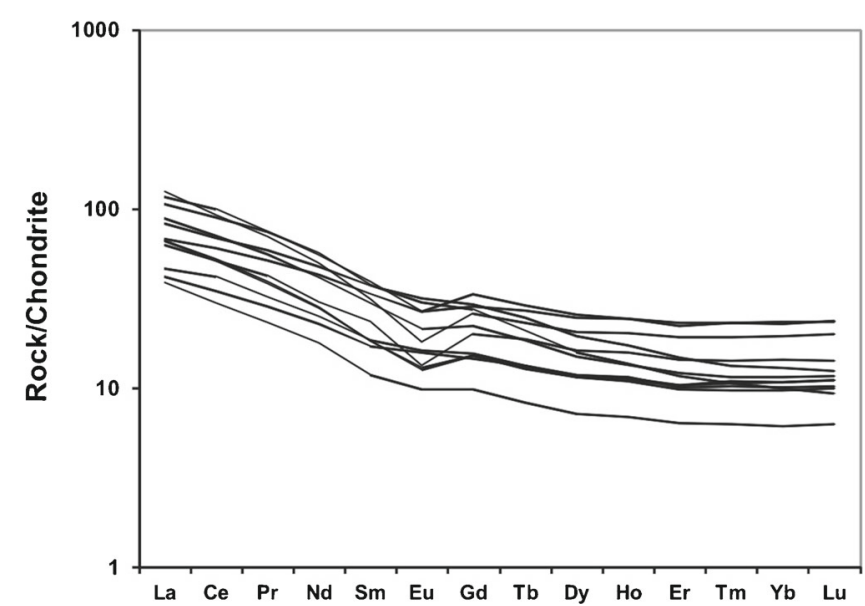

Figure 12. Chondrite normalized REE plot (Sun and McDonough 1989) for the newer dolerite dykes of the study area.

of Singhbhum region (Bose 2008; Mir et al. 2010, 2011, 2013). On the basis of detailed geochemical studies of newer dolerite dykes of Singhbhum craton, Mir et al. (2010) suggested that these dykes were derived from a mantle source which has beenmetasomatized by a subduction component (e.g., fluids derived by dehydration of the subducting slab). It has also been demonstrated that newer dolerites show geochemical signatures similar to those of back-arc basaltic rocks (Mir et al. 2011, 2013). With a backdrop of this knowledge we made an attempt to understand the tectonic settings of the newer dolerite dykes of our study area in terms of a few discrimination diagrams using relatively immobile major and trace elements. In tectonic discrimination diagrams of $\mathrm{TiO}_{2}-\mathrm{MnO} * 10-\mathrm{P}_{2} \mathrm{O}_{5} * 10$ (after Mullen 1983), Cr-Y (Pearce 1982), Ti-V (Shervais 1982) and 3Zr-Nb-Y (Meschede 1986) the plots (figure 14) of the dolerite rocks of study area mostly fall in the fields of ocean floor, oceanic ridge, and volcanic arc basalt suggesting a possible arc-back arc setting for newer dolerites of present study.

Chemical composition of constituent minerals is also important to understand tectonic setting. Partition of elements like $\mathrm{Al}, \mathrm{Si}, \mathrm{Ti}$ into clinopyroxene structure may also provide evidences for tectonic environment (Leterrier et al. 1982; Burns 1985; Loucks 1990; Koksal 2003). In some covariation plots with $\mathrm{Ti}, \mathrm{Na}, \mathrm{Al}(\mathrm{t}), \mathrm{Al}(\mathrm{IV})$ contents of clinopyroxenes (pfu), plots of clinopyroxene composition of newer dolerite dyke of our study area occupy the 'Arc' fields and the field for 'Boninite' (figure 15a, b, c). This possibly suggests crystallization of clinopyroxene and evolution of newer dolerite of Keonjhar area in an arc setting. 


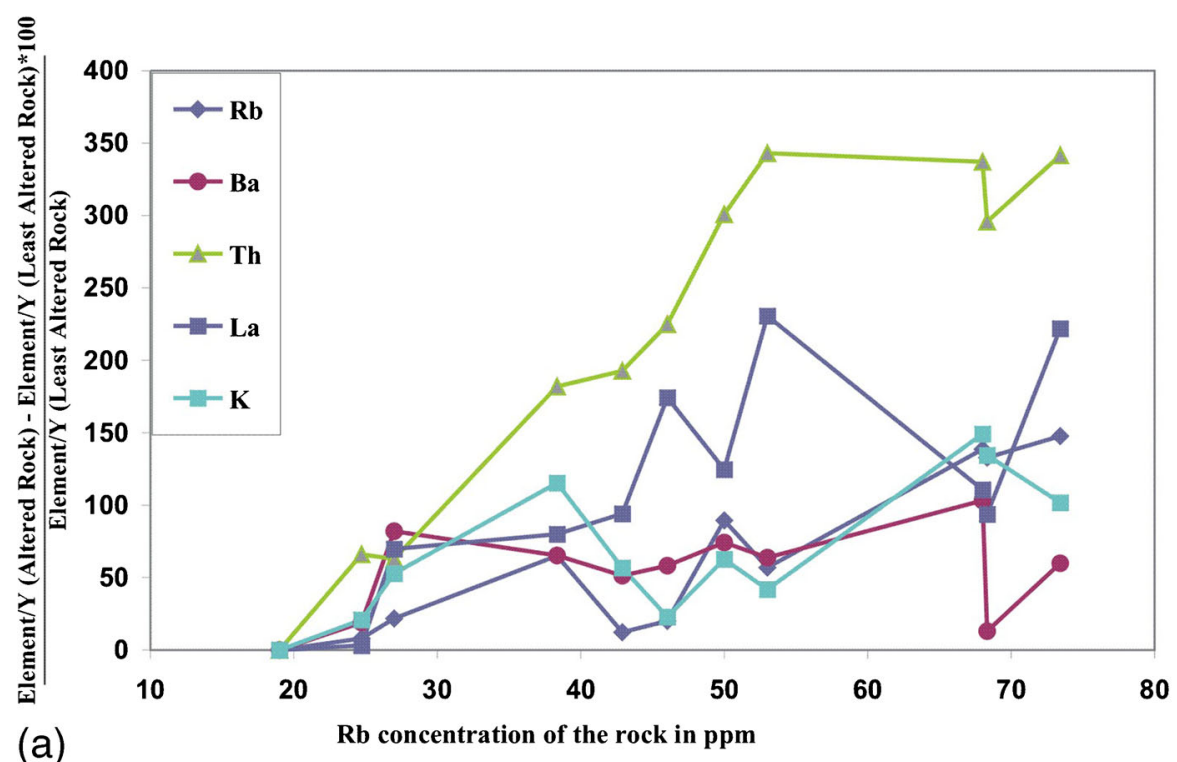

(a)

Rb concentration of the rock in ppm

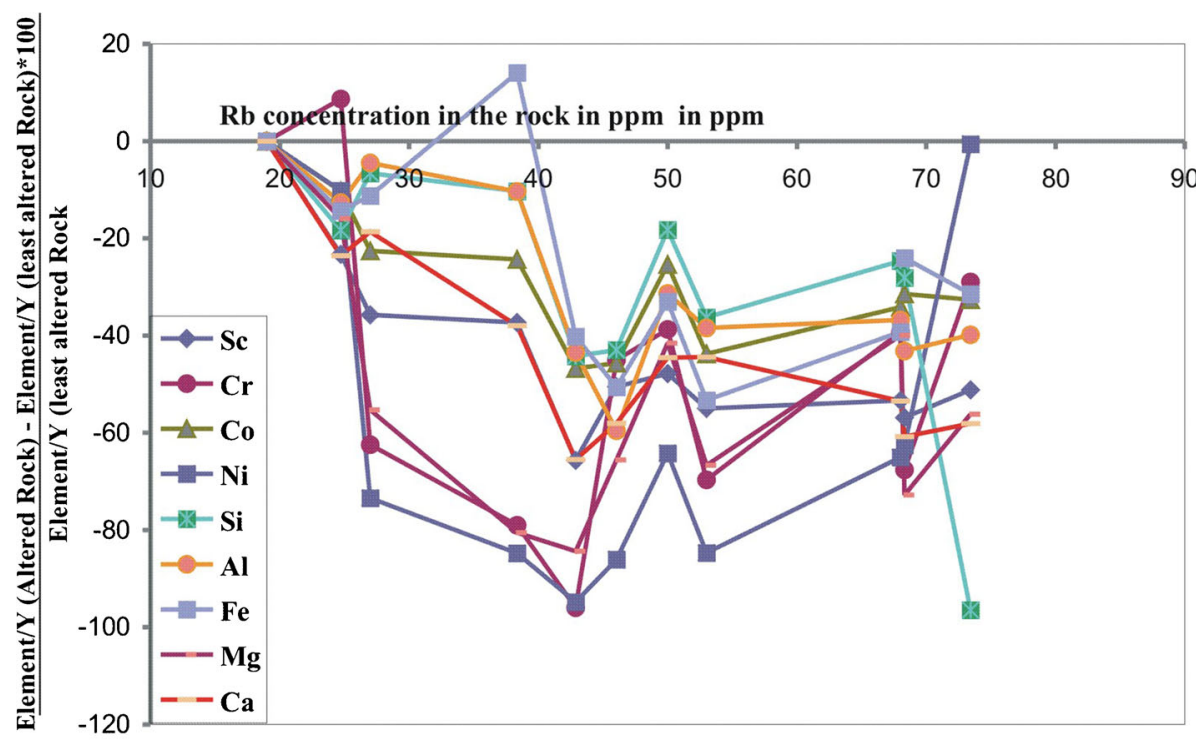

(b)

Figure 13. Graph showing the effects of increasing alterations on element concentrations in newer dolerite rocks. Y axis denotes alteration index of different elements while $\mathrm{X}$ axis represents absolute $\mathrm{Rb}$ concentrations of different altered samples.

\section{Discussion}

Mafic dykes are important components of the Proterozoic rock record and act as significant time markers within stabilized Archean cratons (Ernst and Buchan 2001; Bleeker 2004). In India, the Proterozoic mafic dykes are found in the major cratonic blocks of Aravalli craton, Bundelkhand craton, Dharwar craton, and Singhbhum cratons under different extensional and compressional tectonic regimes (Murthy 1987, 1995; Saha 1994; Halls et al. 2007; Pati et al. 2008). In Singbhum region, newer dolerite dykes exhibit mineralogical and chemical compositions which point towards emplacement in an arc setting in which hydrothermal activity and alteration are common features during emplacement (Sengupta and Ray 2012). Albitisation of plagioclase, bastitisation of orthopyroxene, and development of fibrous amphibole (tremolite-actinolite) from clinopyroxene are all considered products of hydrothermal activity in oceanic conditions (Mottl and Holland 1978). Geochemical signatures of subduction related processes in a back arc setting in newer dolerite dykes of Singbhum pluton have been reported by several workers (Bose 2008; Mir et al. 2010; Sengupta and 


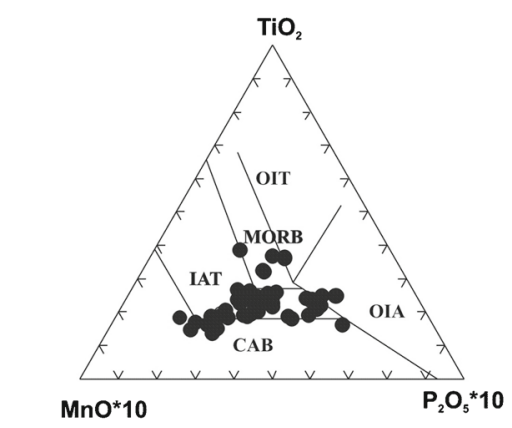

(a)

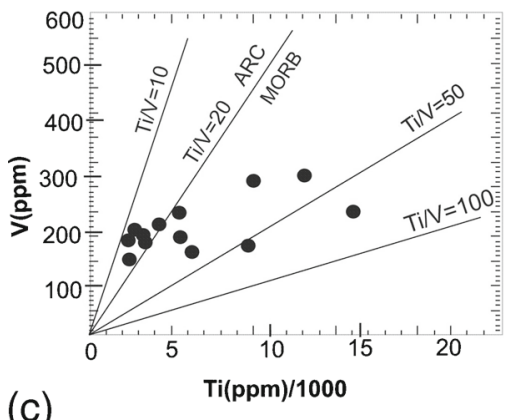

(c)

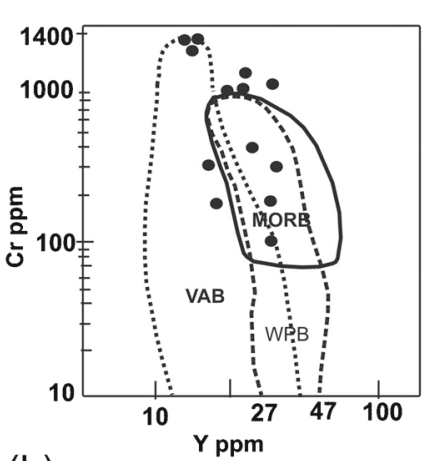

(b)

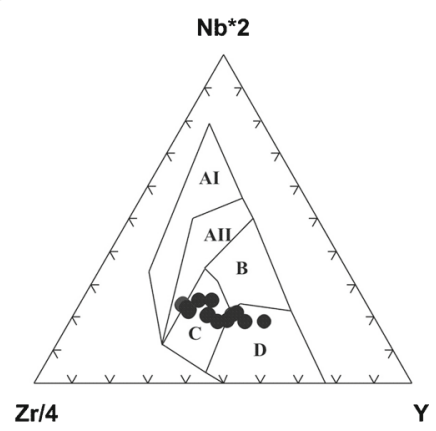

(d)

Figure 14. Tectonioc discrimination diagrams of newer dolerite dykes of Keonjhar area using major and trace element abundances.

Ray 2012). Similar features of mineralogical alteration have also been reported from other Proterozoic mafic rocks of India. The Proterozoic mafic dykes within Bundelkhand Granite Massif (BGM) show clouded feldspar, chloritized or amphibolitized clinopyroxenes as a result of hydrothermal alteration (Mallikharjuna Rao et al. 2005). One of the first detailed studies on the clouded feldspar in dykes on regional scale was carried out by Pichamuthu (1959) from Dharwar craton. Subsequently, it has been realized that such feldspar clouding, specially in Proterozoic mafic dyke swarms, has significant tectonic implications (e.g., Zhang and Halls 1995). Early Proterozoic mafic dykes of Kalyadi area of western Dharwar craton also exhibit tea coloured feldspar, i.e., clouded feldspar and secondary amphiboles around clinopyroxenes (Chandrasekharam et al. 2008).

Although reports on mineralogical alteration in Proterozoic mafic dykes of India are fairly common (Mallikharjuna Rao et al. 2005; Sengupta and Ray 2012), detailed studies on behaviour of major trace elements during such alterations have hardly been attempted. In the present research we have identified the alteration features of some important minerals like plagioclase, clinopyroxene, orthopyroxene, etc., and have made an attempt to find out chemical changes associated with such mineralogical alterations of the mafic dykes. Studying the major and trace element abundances of the altered newer dolerite dykes, we have observed that elements like Rb, Ba, Th, La, K have been added whereas elements like $\mathrm{Sc}, \mathrm{Cr}, \mathrm{Co}, \mathrm{Ni}, \mathrm{Si}$, $\mathrm{Al}, \mathrm{Fe}, \mathrm{Mg}, \mathrm{Ca}$ have suffered removal from the rock during the alteration process. It has also been established that the evolution and emplacement of newer dolerite dykes had occurred in an arc-back arc setting as evidenced from different tectonic diagrams (figures 14 and 15). In general, it has been observed that alteration processes of mafic rocks in an oceanic setting yield somewhat consistent chemical changes (Frey et al. 1974; Mottl 1983). Greenough et al. (1990) have documented quantitatively, the effects of alteration on hotspot basalts from sunken oceanic island in the Indian Ocean. They have shown that the mineralogical changes involve chemical additions of $\mathrm{K}, \mathrm{Rb}, \mathrm{Cs}, \mathrm{Li}$, $\mathrm{Si}, \mathrm{Sc}, \mathrm{Fe}$, etc., and removal of $\mathrm{Ca}, \mathrm{Mg}, \mathrm{Mn}, \mathrm{Ni}$ and others. Similar geochemical studies have also been performed in ophiolitic basalts as well as oceanfloor basalts (Gills and Robinson 1985, 1988). The newer dolerite dykes of the Keonjhar area, which have suffered several mineralogical changes due to hydrothermal alteration along with addition and removal of several elements, may represent a casestudy of hydrothermal activity on arc related mafic rocks. 

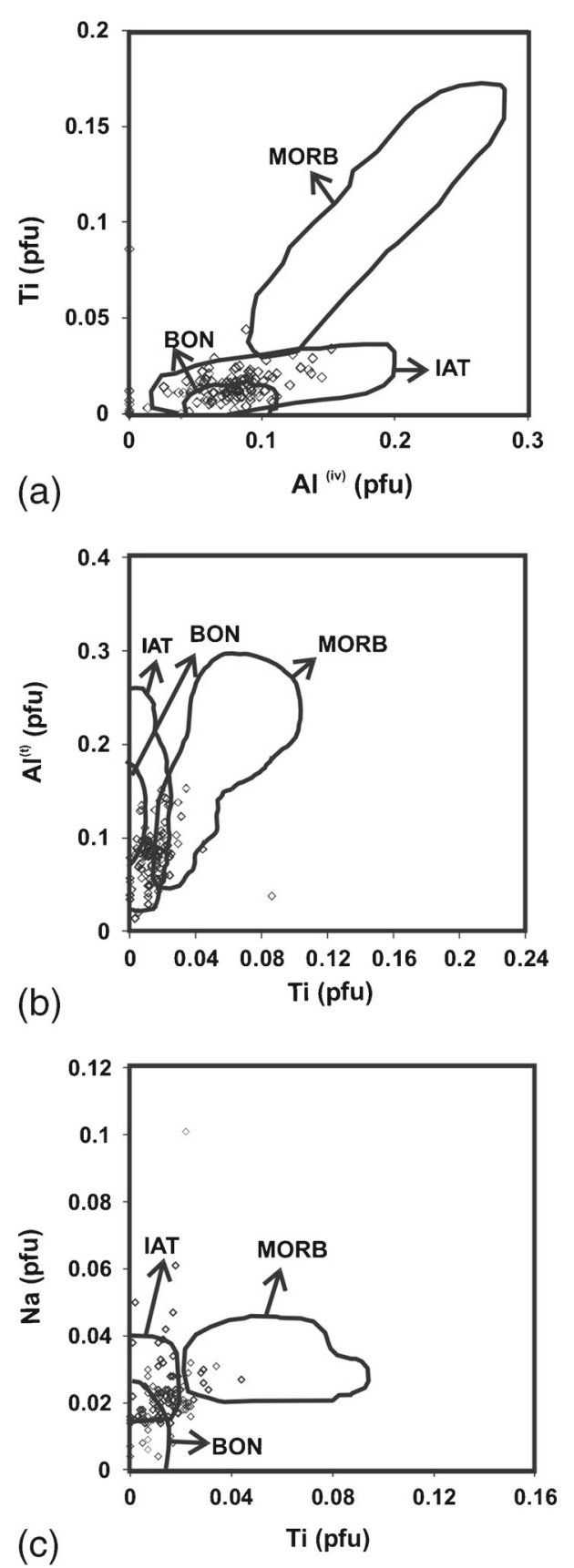

Figure 15. Tectonic discrimination diagrams of newer dolerite dykes of Keonjhar area using partition of elements like Al, Si, Ti into clinopyroxene structure. IAT: Island Arc Tholeiite, BON: Boninite, MORB: Mid Oceanic Ridge Basalt.

\section{Acknowledgements}

The authors thank the Department of Science and Technology, New Delhi for providing research grant for the present work. They also thank the Head of the Department of Geology, Presidency University for providing facilities to carry out this work.

\section{References}

Armbrustmacher T J and Banks N G 1974 Clouded plagioclase in metadolerite dykes, southeastern Bighorn Mountains, Wyoming; Am. Mineral. 59 656-665.

Backman J, Duncan R A et al. 1988 Proc. ODP, Init. Repts 115 College Station, TX (Ocean Drilling Program), doi: 10.2973/odp.proc.ir.115.1988.

Basu A R, Ray S L, Saha A K and Sarkar S N 1981 Eastern Indian 3800 million year old crust and early mantle differentiation; Science 212 1502-1506.

Bleeker W 2004 Taking the pulse of planet Earth: A proposal for a new multi-disciplinary flagship project in Canadian solid Earth Sciences; Geosci. Canada 31 179-190.

Bose M K 2008 Proterozoic dykes from Singhbhum granite pluton; In: Indian dykes (eds) Srivastava R K, Sivaji Ch and Rao C (New Delhi: Narosa Publ.), pp. 413-445.

Burns L E 1985 The border ranges ultramafic and mafic complex, southcentral Alaska: Cumulate fractionates of island arc volcanics; Can. J. Earth. Sci. 22 1020-1038.

Chandrasekharam D, Mellusu L, Cucciniello C, Mathew B and Perini G 2008 Petrogenesis of E-W trending dykes from Kalyadi, Dharwar craton, southwerstern India; In: Indian dykes (eds) Srivastava R K, Sivaji Ch and Rao C (New Delhi: Narosa Publ.), pp. 199-214.

Deer W A, Howie R A and Jussman J 1997 An Introduction to the Rock-Forming Minerals; The English Language Book Society and Longman, London.

Devaraju T C, Alapieti T T, Sudhakara T L and Kaukonen R J 2008 Mafic dyke swarms of volcanic arc, ocean floor, and N-MOR basalt affinity with destructive plate margin emplacement features in the northern segment of western Dharwar craton; In: Indian dykes (eds) Srivastava R K, Sivaji Ch and Rao C (New Delhi: Narosa Publ.), pp. 215-237.

Dunn J A 1929 The geology of north Singhbhum including parts of Ranchi and Manbhum districts; Geol. Surv. India Memoir 54(2) 166p.

Dunn J A and Dey A K 1942 Geology and petrology of eastern Singhbhum and surrounding areas; Geol. Surv. India Memoir 69(2) 261-456.

Ernst R E and Buchan K L 2001 Large mafic magmatic events through time and links to mantle-plume heads; In: Mantle plumes: Their identification through time (eds) Ernst R E and Buchan K L, Geol. Soc. Am. Spec. Paper $352483-575$.

Frey F A, Bryan W B and Thompson G 1974 Atlantic Ocean floor: Geochemistry and petrology of basalts from legs 2 and 3 of the Deep Sea Drilling Project; J. Geophys. Res. 79 5507-5527.

Gills K M and Robinson P T 1985 Low-temperature alteration of the extrusive sequence, Troodos ophiolite, Cyprus; Can. Mineral 23 431-441.

Gills K M and Robinson P T 1988 Distribution of alteration zones in the upper oceanic crust; Geology 16 262-266.

Goswami J N, Mishra S, Wiedenbeck M, Ray S L and Saha A K 19953.55 Ga old zircon from SingbhumOrissa iron ore craton, eastern India; Curr. Sci. 69 1008-1011.

Greenough John D, Fryer Brian J and Robinson Paul T 1990 Geochemical effects of alteration on mafic rocks from Indian ocean site 706; Proceedings of the Ocean Drilling Program, Scientific Results 115 85-92.

Irvine T A and Baragar W R A 1971 A guide to chemical classification of common volcanic rocks; Can. J. Earth Sci. 8 523-548.

Halls H C and Palmer H C 1990 The tectonic relationship of two early Proterozoic dyke swarms to the Kapuskasing 
structural zone: A paleomagnetic study; Can. J. Earth Sci. 27 78-103.

Halls H C, Palmer H C, Bates M P and Phenney W C 1994 Constraints on the nature of the Kapuskasing structural zone from the study of Proterozoic dyke swarms; Can. J. Earth Sci. 31 1182-1196.

Halls H C, Kumar A, Srinivasan R and Hamilton M A 2007 Paleomagnetism and $\mathrm{U}-\mathrm{Pb}$ geochronology of easterly trending dykes in the Dharwar craton, India: Feldspar clouding, radiating dyke swarms and the position of India at $2.37 \mathrm{Ga}$; Precamb. Res. 151 47-68.

Hellman P I, Smith R E and Henderson P 1979 The mobility of rare earth elements: Evidence and implications from selected terrains affected by burial metamorphism; Contrib. Mineral. Petrol. 71 23-44.

Hynes A 1980 Carbonatization and mobility of Ti, Y and $\mathrm{Zr}$ in Ascot Formation metabasalts, southeast Quebec; Contrib. Mineral. Petrol. 75 79-87.

Johnson P R, Kattan F H and Al-Saleh A M 2004 Neoproterozoic ophiolites in the arabian shield: Field relations and structure; In: Developments in Precambrian Geology (eds) Timothy M Kusky and Condie K C (series editor), Elsevier, 13 129-162.

Jones H C 1934 The iron ore deposits of Bihar and Orissa; Geol. Surv. India Memoir 63(2) 167-302.

Knopf E B and Jonas A I 1929 The geology of the crystalline rocks of Baltimore County; In: Baltimore County, Maryland Geol. Survey, pp. 97-199.

Koksal F 2003 Petrology of the phlogopite-bearing ultramafic-mafic plutonic rocks within Central Anatolian Crystalline complex, Turkey; Ph.D. Thesis.

Krishnan M S 1936 The dyke rocks of Keonjhar state, Bihar and Orissa; Rec. Geol. Surv. India 71 105-120.

Leake B E, Woolley A R, Arps C E S, Birch W D, Gilbert M C, Grice J D, Hawthorne F C, Kato A, Kisch H J, Krivovichev V G, Linthout K, Larid J, Mandarino J A, Maresch W V, Nickel E H, Rock N M S, Schmacher J C, Smith D C, Stephenson N C N, Ungaretti L, Whittaker E J W and Youzhi G 1997 Nomenclature of amphiboles: Report of the subcommittee on amphiboles of the International Mineralogical Association, Commission on New Minerals and Mineral Names; Am. Mineral. 82 1019-1037.

Le Bas M J 2000 IUGS reclassification of the high-Mg and picritic volcanic rocks; J. Petrol. 41 1467-1470.

Leterrier J, Maurry R C, Thonon P, Girard D and Marchal M 1982 Clinopyroxene composition as a method of identification of the magmatic affinites of paleo-volcanic series; Earth Planet. Sci. Lett. 59 139-154.

Loucks R R 1990 Discrimination of ophiolitic from nonophiolitic ultramaficmafic allochthons in orogenic belts by the $\mathrm{Al} / \mathrm{Ti}$ ratio in clinopyroxene; Geology 18 346-349.

MacGregor A G 1931 Clouded feldspars and thermal metamorphism; Min. Mag. 22 524-538.

Mallick A K and Sarkar A 1994 Geochronology and geochemistry of mafic dykes from precambrians of Keonjhar Orissa; India Min. 48 3-24.

Mallikharjuna Rao J, Poornachandra Rao M, Widdowson M and Kelley S P 2005 Evolution of proterozoic mafic dyke swarms of the Bundelkhand Granite massif, Central India; Curr. Sci. 88(3) 502-506.

Mandal N, Mitra A K, Misra S and Chakraborty C 2006 Is the outcrop topology of dolerite dykes of Precambrian Singhbhum craton fractal?; J. Earth. Syst. Sci. 115 643-660.

Mc Mullin David W A, Barr Sandra M and Raeside Robert P 2010 Very low and low grade metamorphism of mafic volcanic rocks of the Mira terraine (Avalonia), southeastern cape Breton Island, Nova Scotia; Atlantic Geology 46, doi: 10.4138/atlgeol.2010.006.
Meschede M 1986 A method of discriminating between different types of mid ocean ridge basalts and continental tholeiites with the $\mathrm{Nb}-\mathrm{Zr}-\mathrm{Y}$ diagram; Chem. Geol. 56 207-218.

Mir A R, Alvi S H and Balaram V 2010 Geochemistry of mafic dikes in the Singhbhum Orissa craton: Implications for subduction-related metasomatism of the mantle beneath the eastern Indian craton; Inter. Geol. Rev. 52 79-94.

Mir A R, Alvi S H and Balaram V 2011 Geochemistry of the mafic dykes in parts of the Singhbhum Granitoid Complex: Petrogenesis and tectonic setting; Arab. J. Geosci. 4 933-943.

Mir A R, Alvi S H, Balaram V, Bhat F A, Sumira Z and Dar S A 2013 A subduction zone geochemical characteristic of the newer dolerite dykes in the Singhbhum craton, Eastern India; Int. Res. J. Geol. Mining 3 213-223.

Misra S, Deomurari M P, Wiedenbeck M, Goswami J N, Ray S and Saha A K $1999{ }^{207} \mathrm{~Pb} /{ }^{206} \mathrm{~Pb}$ zircon age and the evolution of the Singhbhum craton, eastern India: An ion microprobe study; Precamb. Res. 93 139-151.

Misra S 2006 Precambrian chronostratigraphic growth of Singhbhum-Orissa Craton, eastern Indian Shield: An alternative model; J. Geol. Soc. India 67 356-378.

Mottl M J 1983 Metabasalts, axial hot springs, and structure of hydrothermal systems at mid-ocean ridges; Geol. Soc. Am. Bull. 94 161-180.

Mottl M J and Holland H D 1978 Chemical exchange during hydrothermal alteration of basalt by sea waterExperimental results for major and minor components of seawater; Geochim. Cosmochim. Acta 42 1103-1115.

Mukherjee J, Beukes N J, Armstrong R A, Zimmermann V, Ghosh G and Medda R A 2008 Dating the oldest greenstone in India: A $3.51 \mathrm{Ga}$ precise U-Pb SHRIMP zircon age for dacitic lava of the southern iron ore group, Singbhum Craton; J. Geol. 116 449-461.

Mukhopadhyay D 2001 The Archaean nucleous of Singbhum: The present state of knowledge; Gondwana Res. 4(3) 307-318.

Mullen E D $1983 \mathrm{MnO} / \mathrm{TiO}_{2} / \mathrm{P}_{2} \mathrm{O}_{5}$ : A major element discriminant for basaltic rocks of oceanic environments and its implication for petrogenesis; Earth Planet. Sci. Lett. $6253-62$.

Murthy N G K 1987 Mafic dyke swarms of the Indian shield; In: Mafic dyke swarms (eds) Halls H C and Fahrig W F, Geol. Assoc. Canada Spec. Paper 34 393-400.

Murthy N G K 1995 Proterozoic mafic dykes in southern peninsular India; Geol. Soc. India Memoir 33 81-98.

Pati J K, Raju S, Malviya V P, Bhusan R, Prakash K and Patel S C 2008 Mafic dykes of Bundelkhand Craton, central India: Field, petrological and geochemical characteristics; In: Indian dykes (eds) Srivastava R K, Sivaji $\mathrm{Ch}$ and Rao C (New Delhi: Narosa Publ.), pp. 548-569.

Pearce J A 1982 Trace element characteristics of lavas from destructive plate boundaries; In: Andesites (ed.) Thorpe R S, John Wiley and Sons, pp. 525-548.

Pichamuthu C S 1959 The significance of clouded plagioclase in the basic dykes of Mysore state, India; J. Geol. Soc. India 1 68-79.

Plumper O, Piazolo S and Austrheim H 2012 Olivine pseudomorphs after serpentinized orthopyroxene record transient oceanic lithospheric mantle dehydration (Leka Ophiolite Complex, Norway); J. Petrol. 53(9) 1943-1968.

Poldervanrt A and Gilkey A K 1954 On clouded feldspars; Am. Mineral. 39 75-91.

Robertson L D M and Van Breeman O 1970 The southern satellite dykes of the Great Dyke, Rhodesin; Geol. Soc. South Af. Spec. Publ. I 621-644. 
Roy A B and Bhattacharya H N 2012 Tectonostratigraphic and geochronologic reappraisal constraining the growth and evolution of Singhbhum Archean craton, eastern India; J. Geol. Soc. India 80 455-469.

Saha A K 1948 Kolhan series: Iron ore series boundary to the east and southwest of Chaibasa; Sci. Cult. 14 77-79.

Saha A K 1952 On porphyry dykes near Dalsara, Mayurbhanj; Sci. Cult. 18 250-253.

Saha A K 1994 Crustal evolution of north SinghbhumOrissa, eastern India; Geol. Soc. India Memoir 27341.

Saha A K, Bose M K, Sankaran A V and Bhattacharyya T K 1972 Petrology and geochemistry of the ultramafic intrusion of Keshargaria, Singhbhum, Bihar; J. Geol. Soc. India 13 113-121.

Saha A K, Sankaran A V and Bhattacharyya T K 1973 Geochemistry of the newer dolerite suite of intrusions within the Singhbhum granite; J. Geol. Soc. India 14 324-346.

Sengupta P and Ray A 2012 Newer dolerite dykes, Jharkhand, India: A case study of magma generation, differentiation and metasomatism in a subduction zone setting; Geochem. J. 46 477-491.

Seyfried W E Jr, Berndt M E and Seewald J S 1988 Hydrothermal alteration processes at mid ocean ridges: Constraints from thermal alteration experiments, hotspring fluids and composition of the oceanic crust; Can. Mineral. 26 787-804.

Shervais J W 1982 Ti-V plots and the petrogenesis of modern and ophiolitic lavas; Earth Planet. Sci. Lett. 59 101-118.

Sun S S and McDonough W F 1989 Chemical and isotopic systematics of oceanic basalts: Implication for mantle composition and processes; Geol. Soc. Spec. Publ. 42 313-345.

Zhang B 1988 Preliminary study on Proterozoic dyke swarms in north Sanxin; M.Sc. thesis, Peking University (in Chinese with English Abstract).

Zhang B and Halls H C 1995 The origin and age of the feldspar clouding in the Matachewan dyke swarm; In: Phys. Chem. Dykes (eds) Baer G and Heimann A, Balkema, Rotterdam, pp. 171-176. 